\title{
RESEARCH AND DEVELOPMENT PROGRAM PLAN FOR GEOPRESSURE-GEOTHERMAL RESOURCES
}

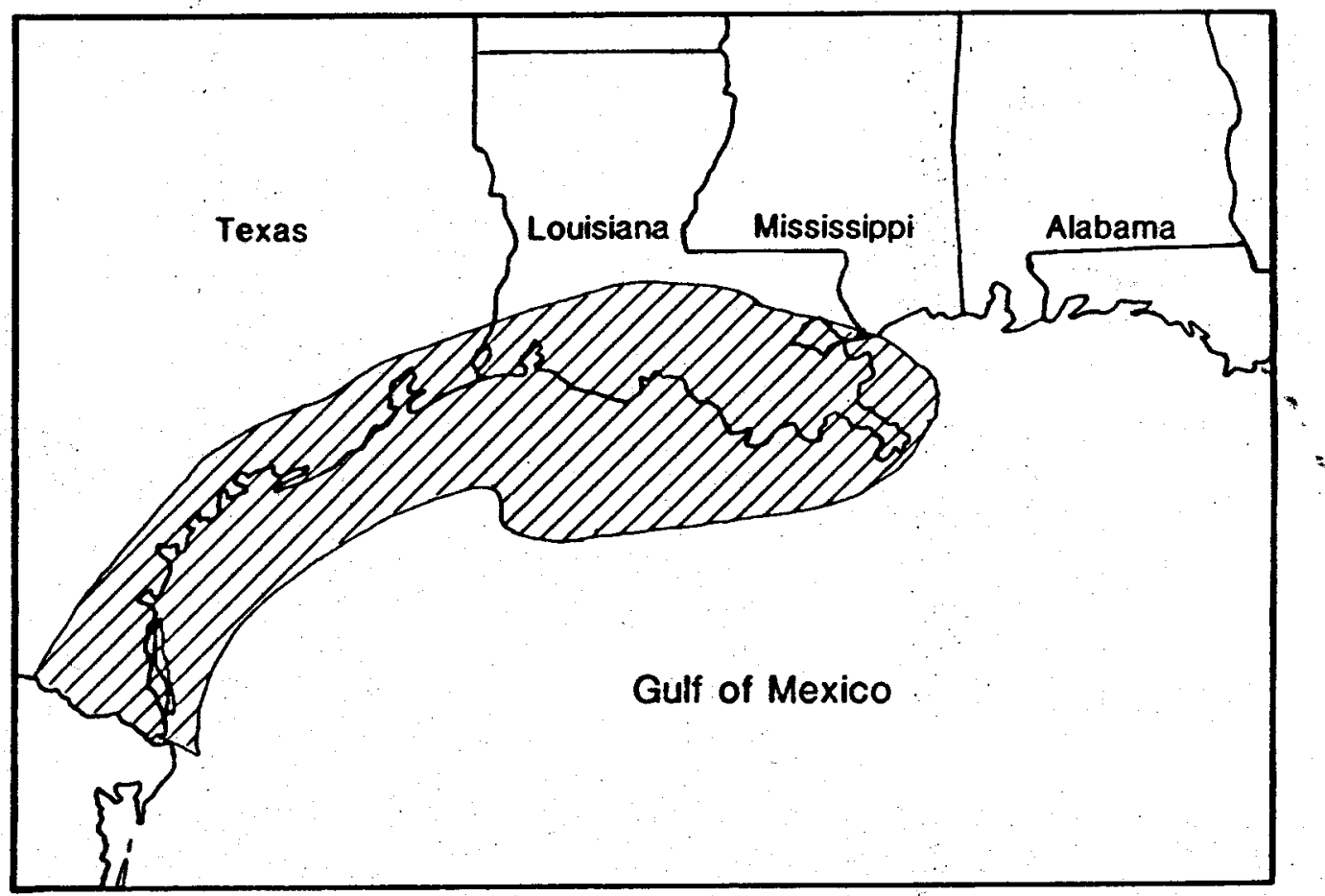

December, 1980

Division of Geothermal Energy Assistant Secretary for Resource Applications Department of Energy 


\section{DISCLAIMER}

This report was prepared as an account of work sponsored by an agency of the United States Government. Neither the United States Government nor any agency Thereof, nor any of their employees, makes any warranty, express or implied, or assumes any legal liability or responsibility for the accuracy, completeness, or usefulness of any information, apparatus, product, or process disclosed, or represents that its use would not infringe privately owned rights. Reference herein to any specific commercial product, process, or service by trade name, trademark, manufacturer, or otherwise does not necessarily constitute or imply its endorsement, recommendation, or favoring by the United States Government or any agency thereof. The views and opinions of authors expressed herein do not necessarily state or reflect those of the United States Government or any agency thereof. 


\section{DISCLAIMER}

Portions of this document may be illegible in electronic image products. Images are produced from the best available original document. 


\section{RESEARCH AND DEVELOPMENT PROGRAM PLAN FOR GEOPRESSURE-GEOTHERMAL RESOURCES}

This document presents the Department of Energy's Research and Development Program Plan for Geopressure-Geothermal Resources for FY81 through FY86. The Plan provides an overall perspective for these energy sources and describes the Department of Energy's R\&D program directed toward resolving the geologic, technical, and economic barriers that currently impede their development. The topics covered in the Program Plan include:

(1) The program goals, objectives, and strategy;

(2) The status of resource definition, research and technology development including the program milestones;

(3) The supporting environmental activities;

(4) The management plan for the program;

(5) The financial resource requirements. 


\section{TABLE OF CONTENTS}

EXECUTIVE SUMMARY

CHAPTER 1.0 PROGRAM DESCRIPTION

1.1 THE GEOPRESSURE-GEOTHERMAL RESOURCE

1.1.1 Resource Description $1-1$

1.1.2 Origin of the Resource Base $\quad 1-1$

1.1.3 Extent of the Resource 1-1

1.2 GEOPRESSURE-GEOTHERMAL RESOURCE DEVELOPMENT 1-6

1.2.1 Developing the Geopressure-Geothermal Resources $1-6$

1.2.2 Total Energy Systems $\quad 1-6$

1.3 NEED FOR A FEDERAL ROLE $\quad 1-8$

$\begin{array}{ll}\text { 1.3.1 Support of National Priorities } & 1-8\end{array}$

1.3.2 Overcoming Historical Perceptions $\quad 1-8$

1.3.3 Coordination of Federal and Private Sector Involvement $1-10$

1.4 PROGRAM RATIONALE $1-10$



1.4.2 Program Objectives $1-10$

1.4.3 Program Activities and Accomplishments $1-11$

1.4.4 Program Priorities $1-14$

1.4.5 Implementation Strategy $\quad 1-14$

1.4.6 Major Program Milestones 1-16

CHAPTER 2.0 TECHNICAL PROGRAM

2.1 INTRODUCTION 2-1

2.2 DETAILS OF THE TECHNICAL PROGRAM

2.2.1 Activity 1 . Resource Definition 2-4

2.2.1.1 Purpose 2-4

2.2.1.2 Approach 2-4

2.2.1.3 Discussion of Activity Components 2-4

-Geologic Studies $\quad 2-4$

-Well Testing $\quad 2-6$

2.2.2 Activity 2. Demonstration of Recovery Potential 2-17

$\begin{array}{ll}\text { 2.2.2.1 Purpose } & \text { 2-17 }\end{array}$

2.2.2.2 Approach $2-18$

2.2.2.3 Discussion of Activity Components 2-18

-Recovery Technology $\quad 2-18$

- Supporting Research $\quad 2-20$

-Analysis of Development Constraints $\quad 2-21$

2.3 GENERAL PROGRAM SUPPORT 2-23

$2.4 \quad$ FUTURE NEEDS AND PRIORITIES $\quad 2-24$

CHAPTER 3.0 ENVIRONMENTAL STUDIES

3.1 INTRODUCTION $3-1$

3.1.1 Subsidence $3-1$

3.1.2 Fluid Disposal $3-1$

3.1.3 Other Concerns 3-1

3.2 PURPOSE $3-1$

3.3 APPROACH $3-2$

3.4 DISCUSSION OF ACTIVITY COMPONENTS

3.4.1 Prospect-Specific Activities 3-2

3.4.2 Generic Environmental Activities 3-5

CHAPTER 4.0 MANAGEMENT PLAN

CHAPTER 5.0 FUNDING REQUIREMENTS 


\section{LIST OF EXHIBITS}

Page

Exhibit 1-1 Occurrence of Geopressured Sediments in the Gulf Coast Basin $\quad 1-2$

Exhibit 1-2 Cross Section Showing Deposition Along the Gulf Coast $\quad 1-3$

Exhibit 1-3 Estimates of Natural Gas in Geopressured Aquifers $\quad 1-4$

Exhibit 1-4 Methane and Thermal Resource Base in Geopressured Aquifers 1-5

$\begin{array}{ll}\text { Exhibit 1-5 Geopressured Basins of the United States } & 1-7\end{array}$

$\begin{array}{ll}\text { Exhibit 1-6 Flow Diagram of a Total Energy System } & 1-9\end{array}$

Exhibit 1-7 Texas Geopressured Fairways and Primary Prospects $\quad 1-12$

Exhibit 1-8 Louisiana Priority Geopressured Prospects $\quad 1-13$

$\begin{array}{ll}\text { Exhibit 1-9 Major Components of Implementation Strategy } & 1-15\end{array}$

Exhibit 1-10 Major Milestones for Assessment of Resource Potential . 1-17

$\begin{array}{lll}\text { Exhibit 2-1 } & \text { Technical Program Activities } & 2-2\end{array}$

Exhibit 2-2 Milestones for Assessment of Resource Potential $2-3$

$\begin{array}{ll}\text { Exhibit 2-3 Resource Definition Activity } & 2-5\end{array}$

Exhibit 2-4 Particulars of DOE's Two Well Testing Programs $\quad 2-7$

Exhibit 2-5 Location of DOE Louisiana Wells of Opportunity $\quad 2-9$

Exhibit 2-6 $\quad$ Location of DOE Texas Wells of Opportunity $\quad 2-10$

Exhibit 2-7 Wells of Opportunity Selection Guidelines $\quad 2-11$

Exhibit 2-8 $\quad$ Summary of Well of Opportunity Test Data $\quad 2-12$

Exhibit 2-9 Selection Guidelines for Favorable Reservoirs $\quad 2-14$

Exhibit 2-10 Design Well Tests-In Process $\quad 2-15$

$\begin{array}{lll}\text { Exhibit 2-11 Design Well Tests-Proposed } & \text { 2-16 }\end{array}$

$\begin{array}{ll}\text { Exhibit 2-12 Recovery Potential Activity } & 2-19\end{array}$

Exhibit 3-1 Environmental Studies Activity $3-3$

Exhibit 3-2 Elements of the Environmental Control Plan $3-4$

Exhibit 4-1 Management Organization of the Division of Geothermal Energy 4-2

Exhibit 5-1 Geopressure Program Funding Projections $\quad 5-2$

Exhibit 5-2 Multi-Year Funding Requirements $\quad 5-3$

Exhibit 5-3 Funding Requirements by Major R\&D Phases $\quad 5-3$ 


\section{EXECUTIVESUMMARY}

The objective of the Geopressure-Geothermal Program of the Division of Geothermal Energy, U.S. Department of Energy, is to determine by the end of FY86 the magnitude and economic potential of the geopressure-geothermal resources. This Program Plan describes how the Department of Energy proposes to achieve this objective.

\section{Resource Target}

Geopressured aquifers are underground reservoirs of hot, pressurized waters that contain methane in solution. Such geopressure-geothermal reservoirs are known to occur in the United States along the Gulf of Mexico Coast, the Pacific West Coast, and in Appalachia, as well as in deep sedimentary basins elsewhere in the U.S. Should it be economically feasible to produce the formation waters and extract the chemical, thermal, and mechanical energy in these aquifers, this resource could make a substantial contribution to the nation's energy supply.

Although estimates vary, the geopressure-geothermal resource base (energy in the ground) is projected to be substantial. Estimates of the in-place methane alone range between 1,000 and 50,000 trillion cubic feet (Tcf). The large differences in estimates arise from uncertainties about the geographic area, the size of the reservoirs, and the volume of methane dissolved in the geopressured brines. The U.S. Geological Survey (USGS), in Circular 790, estimates that 5,700 Tcf of natural gas is contained in the waters of sandstone formations in onshore and offshore areas along the Gulf of Mexico.

While the geopressure-geothermal resource base is projected to be substantial, only a small part of the energy within it can be withdrawn from the aquifers and used on the surface. The exact size and number of individual aquifers comprising the resource base and the amount of energy that can be recovered from them are highly uncertain. The technically recoverable methane has been estimated at 50 to 5,000 Tcf. In comparison, the U.S. consumes about $20 \mathrm{Tcf}$ of natural gas per year.

The initial target for the Department of Energy's Geopressure-Geothermal Program is the methane in solution in the onshore coastal areas of Texas and Louisiana. This is due to the larger size and potential recovery of this energy compared to the thermal and mechanical energy, and the large data base available from oil and gas exploration in this area. Subsequent efforts will be directed toward the economic utilization of thermal and mechanical energy and potential geopressure-geothermal resources in other geographic areas.

\section{Need for a Federal Role}

Although the in-place geopressure-geothermal resource base is clearly large, numerous historical perceptions limit industry's interest in pursuing these resources:

- Production from geopressured reservoirs involves large volumes of water and relatively low concentrations of gas. Consequently, these resources have been perceived to be marginally economical in comparison with conventional natural gas resources.

- Previous drilling has been in anticlines or close to faults where oil and gas could be trapped; thus, the reservoirs found to date have been relatively small. By extension, industry assumes that the geopressured aquifers will also be small.

- Subsidence, water disposal, and other issues constitute serious environmental uncertainties that could potentially have large economic consequences to a single firm. 
Given the high initial investment required to define these resources and resolve the environmental uncertainties, no developer has been willing to accept the risk and sponsor the necessary resource definition and associated research. An important aspect of the Department of Energy's role is to accept the risk and thereby accelerate the commercialization of these resources by gathering sufficient and reliable information on them to overcome industry's hesitations. Formulating appropriate policies and incentives for subsequent commercial development by the private sector are also key governmental responsibilities.

\section{Program Objectives}

The main purposes of the current program are to narrow the range of uncertainty on the potential recovery of energy from the geopressure-geothermal resources and to ensure the timely development of these resources as the potential is demonstrated. For these purposes, the Division of Geothermal Energy has established the following objectives:

- Define the magnitude, potential, and economics of the resources.

- Conduct supporting research on reservoir and fluid characteristics.

- Adapt or develop downhole, surface, and disposal technology.

- Identify and mitigate adverse environmental, legal, and institutional issues in order to promote commercialization.

\section{Program Priorities}

To implement this program the following priorities have been established for acquiring and evaluating data on the geopressure-geothermal resources:

- Near-Term Priorities (FY81-82). By the end of FY82, the data from the first 12 Wells of Opportunity and 5 Design Wells will be combined with the results of regional resource characterizations and $R \& D$ activities for a preliminary assessment on the technical and economic feasibility of developing the resources.

- Mid-Term Priorities (FY83-86). By the end of FY86, data from 24 Wells of Opportunity and 12 Design Wells will have been gathered and evaluated, so a comprehensive assessment of the potential recovery of energy from geopressure-geothermal resources can be made. Substantial progress will also be made toward resolving or mitigating environmental, legal, social, and institutional constraints.

- Long-Term Priorities (Beyond FY86). After FY86 it is expected that industry will develop the potential resources. DOE will assist this development by helping resolve impeding constraints by sponsoring advanced technology for extracting mechanical and thermal energy as part of a total energy system.

\section{Program Activities and Accomplishments}

To achieve its stated priorities, the implementation strategy of the Geopressure-Geothermal Program is organized around three activities:

- Resource Definition. The objective of this activity is to build a base of geologic and engineering data, use this data to reduce the uncertainty associated with the size and recoverability of the resources, and establish the location of aquifers suitable for development.

- Demonstration of Recovery Potential. The objective of the second activity is to determine whether energy from the geopressure-geothermal resources can be economically recovered by demonstrating the technical feasibility of producing geopressured aquifers, developing an improved understanding of geopressured reservoir and fluid characteristics through laboratory work and reservoir models, and identifying and mitigating legal and institutional constraints.

- Environmental Studies. The primary objective of the third activity is to anticipate, understand, and develop methods to control possible environmental 
site-specific problems as well as potential generic problems associated with the development of the geopressure-geothermal resources.

The activities of the Geopressure-Geothermal Program are coordinated with the activities of the DOE/DGE Hydrothermal Program and with related programs of other organizations. In particular, the U.S. Geological Survey has had, and continues to have, a significant resource assessment effort within its Geothermal Research Program.

Major efforts have been underway since 1975 at the University of Texas and Louisiana State University to prepare regional definitions of the Gulf Coast geopressure-geothermal resources. This work has identified the geopressured "fairways" and has begun to delineate favorable prospect areas within these fairways that can be developed for long-duration testing.

Two well testing programs are underway to obtain basic data:

- Wells of Opportunity. To reduce uncertainties associated with reservoir and fluid characteristics, DOE initiated its Wells of Opportunity program. These are wells drilled by industry in the search for oil and gas which are found to be unproductive and which can be completed in geopressured reservoirs. Completing these wells in the zones of interest allows DOE to test wells at a lower cost than by drilling new wells. However, the wells may not be in favorable locations and are usually only appropriate for short-term testing.

- Design Wells. Design Wells are drilled for DOE by contractors at designated, prime sites identified through geologic studies. These wells are more expensive than the Wells of Opportunity, but they permit long-term testing in favorable geopressured fairways and reservoirs. These tests can obtain data on the area and thickness of the reservoir, the variability in reservoir characteristics, and long-term production effects.

In addition to the well tests, research and development is being directed toward developing production technology and identifying and resolving economic, institutional, and environmental barriers that might impede commercialization.

\section{Management}

The Division of Geothermal Energy has overall management responsibility for the DOE Geopressure-Geothermal Program. The Program is administered by the Geothermal Energy Branch of the Energy Applications Division at the Nevada Operations Office and the Houston Geopressured Projects Office. Contractors are used for the actual drilling and testing of wells. National laboratories, universities, and industrial research institutions provide much of the supporting research and technology development.

\section{Funding Requirements}

The major part of the funding is devoted to Resource Definition and the selection, design, drilling, and testing of wells. The funding requirements increase from $\$ 36$ million in FY81 to $\$ 47$ million in FY84 before declining to $\$ 40$ million in FY86. The total budget for the six-year, FY81-FY86 period, is $\$ 247$ million. 


\section{CHAPTER 1.0 PROGRAM DESCRIPTION}

\subsection{THE GEOPRESSURE-GEOTHERMAL RESOURCE}

\subsubsection{Resource Description}

Water-bearing reservoirs, characterized by significantly higher temperatures and pressures than their depth would suggest, have been discovered along the Gulf of Mexico and other areas of the United States. These reservoirs, labeled geopressured aquifers, contain three forms of energy:

- Chemical Energy - Because the solubility of methane in brines increases rapidly with pressure and temperature, considerable amounts of natural gas could be contained in these aquifers at geopressured conditions.

- Thermal Energy - The relatively high temperature of the waters could be used for the generation of electricity or for direct heat applications.

- Mechanical Energy - The high pressure of the waters could be used to drive turbines.

Should it be economically feasible to produce the formation waters, extract the methane, utilize the thermal and mechanical energies, and dispose of the produced brines in an environmentally sound way, these reservoirs could make a substantial contribution to the nation's energy supply.

\subsubsection{Origin of the Resource Base}

Large river systems have been depositing vast quantities of sediment in the northern Gulf of Mexico Basin for at least the past 50 million years. The depocenters have shifted northeastward through time from the southern Texas coast to eastern Louisiana, where the present-day Mississippi River is actively continuing this process. Continuous deposition, along with subsidence of the Basin, has produced sediment thicknesses in excess of 50,000 feet. As shown on Exhibit 1-1, geopressured sediments may occur shallower than 6,000 feet and deeper than 15,000 feet.

The deeper section of this sediment accumulation is composed mainly of fine grained material deposited before each major period of deltaic sedimentation began. As the river deltas built-out into the Gulf, each younger deltaic system overrode its predecessor, rapidly covering a wedge of deposits that gradually thickened gulfward, Exhibit 1-2. The weight of the sand caused it to sink into the less dense shale, forming growth faults and thus retarding the normal escape of water through the sand layers to the surface.

With retardation of water expulsion from the sediments, burial, and increased thickening of the sediment pile by further deposition, the pore-fluids were subjected to a greater than normal compressive load, and fluid pressures increased. As temperature increased with burial, thermal expansion of water and clay mineral diagenesis occurred, further increasing the pore-fluid pressures. Also, diagenetic changes occurring in buried sandstones aided the processes of pressure build-up in some areas by restricting fluid flow in these beds.

Thus, geopressuring along the Gulf Coast is the result of rapid and continuous deposition of sediments with subsequent formation of growth faults, fluid expansion and clay mineral diagenesis with increasing temperature, and diagenetic flow reduction in some sandstone beds. All of these factors serve to isolate and maintain high fluid pressures in individual reservoirs.

\subsubsection{Extent of the Resource}

Because of the widespread geological deposition along the Gulf Coastal Plain, the resource base of the gas dissolved in geopressured aquifers is estimated to be substantial. Its exact size and the energy recoverable from it, however, is highly uncertain, as is evidenced by the large differences in resource estimates shown on Exhibit 1-3. The tech- 
Exhibit 1-1

\section{OCCURRENCE OF GEOPRESSURED SEDIMENTS IN THE GULF COAST BASIN}

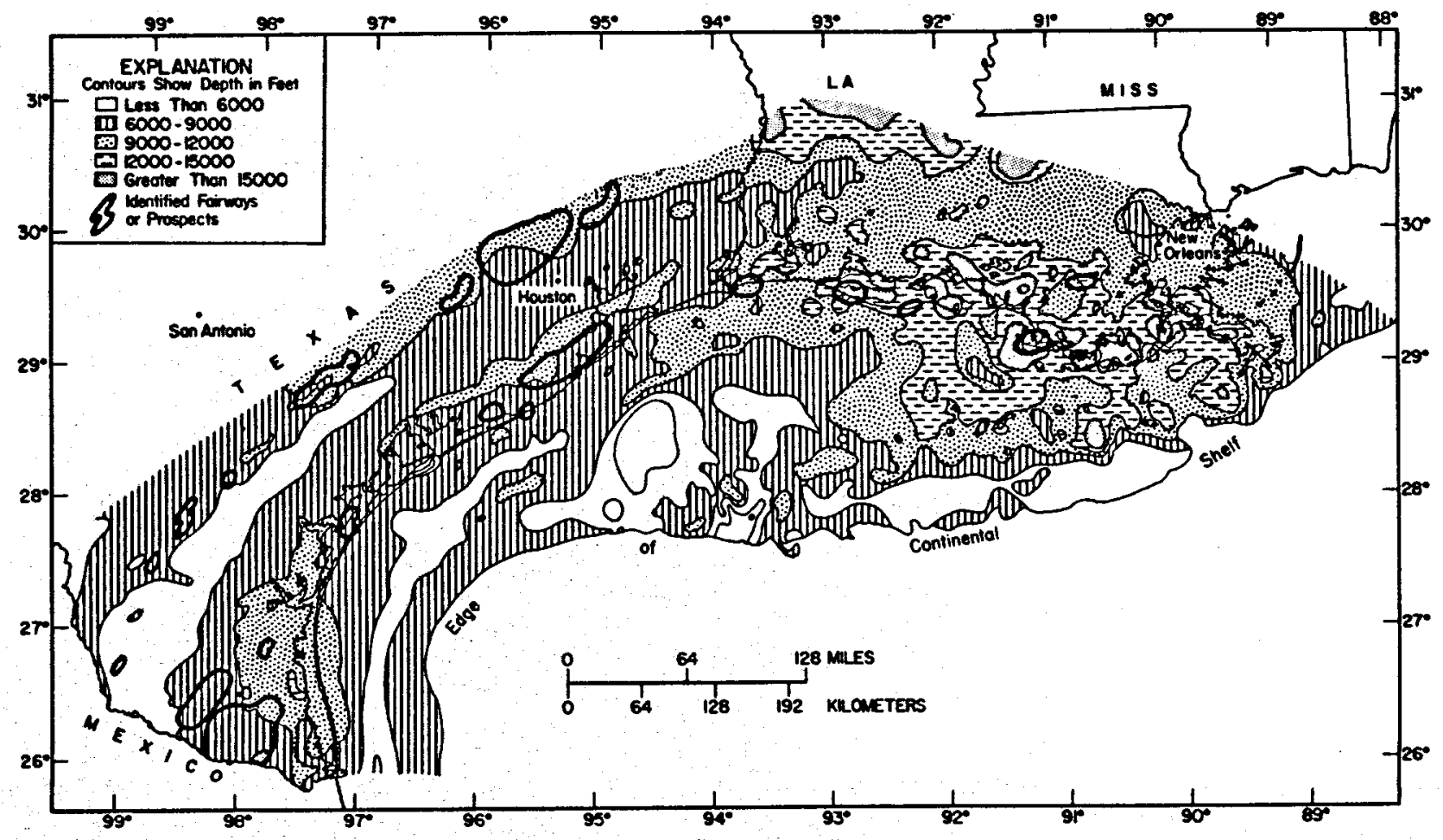

Source : Wallace, 1979 
Exhibit 1-2

\section{CROSS SECTION SHOWING DEPOSITION ALONG THE GULF COAST}

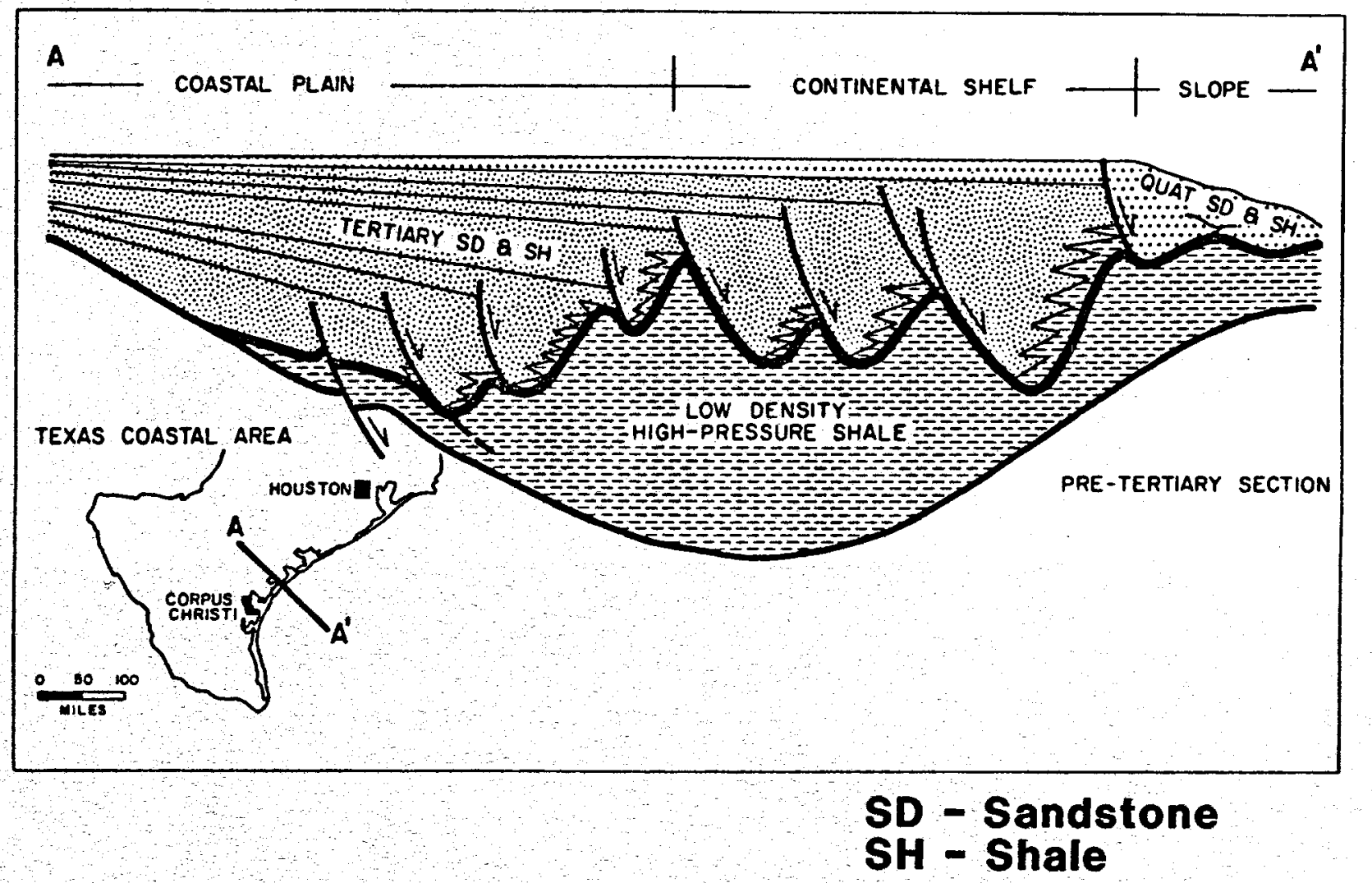

SOURCE: Bruce, 1973 


\section{Exhibit 1-3}

ESTIMATES OF NATURAL GAS IN GEOPRESSURED AQUIFIERS
(Trillions of Cubic Feet)

\section{(Resource Base) \\ Total Methane In-Place}

\section{Recoverable Methane***}

Recovery

\begin{tabular}{|c|c|c|c|c|c|c|c|c|}
\hline Date & Source & Texas & La. & Total & Texas & La. & Total & (\%) \\
\hline 1977 & Jones & - & - & 50,000 & - & - & 5,000 & 10 \\
\hline 1977 & Dorfman (UT) & - & - & 5,700 & 82 & 175 & 257 & 5 \\
\hline 1977 & Hise (LSU) & - & - & 3,000 & - & - & 150 & 5 \\
\hline 1978 & Lewin \& Ássoc." & 300 & 800 & 1,000 & 10 & 40 & 50 & 5 \\
\hline 1978 & Bernard & - & - & - & 40 & 14 & 54 & - \\
\hline 1979 & USGS, \#790 ** & & 1300 & 3.1 & 72 & 25 & 97 & 3 \\
\hline & Offshore & 1,000 & - & $(2,6$ & - & - & 53 & \\
\hline 1980 & $\begin{array}{l}\text { National Petr. } \\
\text { Council*** }\end{array}$ & - & - & & - & - & 81 & MMcf/day \\
\hline
\end{tabular}

* The Lewin estimate for Texas includes only the Frio formation.

** USGS estimate is for sandstone only. The estimate of recoverable resource assumes sufficiently high wellhead pressure to limit subsidence to one meter, based on 1975 information.

*** Assumes no reinjection into the produced aquifer. Reinjection could theoretically increase the recoverable resource by five to six times, but may not be either technically or economically feasible.

**** The production rate in the year 2000 under the most optimistic case for onshore Gulf Coast sandstones.

nically recoverable methane is estimated in these studies to range from 50 to 5,000 Tcf. By comparison, the U.S. consumes about $20 \mathrm{Tcf}$ of gas per year.

The wide variation in estimates reflects the many technological and economic uncertainties involved and the different assumptions and approaches used in various studies. The two general areas where uncertainties arise are in the determination of: (1) the number and quality of geopressured reservoirs, and (2) the volume of methane which may be dissolved in water under varying physical conditions.

While the various studies agree that the general area is underlain by potentially producible geopressured aquifers, each author arrives at different total volumes of geopressured sand within the geopressured interval. For example, Dorfman assumed thick reseryoir sands with an average porosity of 22 percent, while Hise assumed thinner sands and a lower porosity of 20 percent; Jones used a representative subarea which he then extrapolated, with some adjustments, to the entire region.

The National Petroleum Council completed an engineering study in 1980 of eleven identified reservoirs, which was then extrapolated to estimate the production potential of methane from onshore, sandstone Gulf Coast reservoirs.

The U.S. Geological Survey (USGS) Circular 790 estimate for the methane and thermal energy, by location and by reservoir lithology, is displayed on Exhibit 1-4. The USGS estimates of the thermal and methane resource base in the onshore sandstone formations 


\section{Exhibit 1-4 \\ METHANE AND THERMAL RESOURCE BASE \\ IN GEOPRESSURED AQUIFERS \\ (Thousands of Quads)}

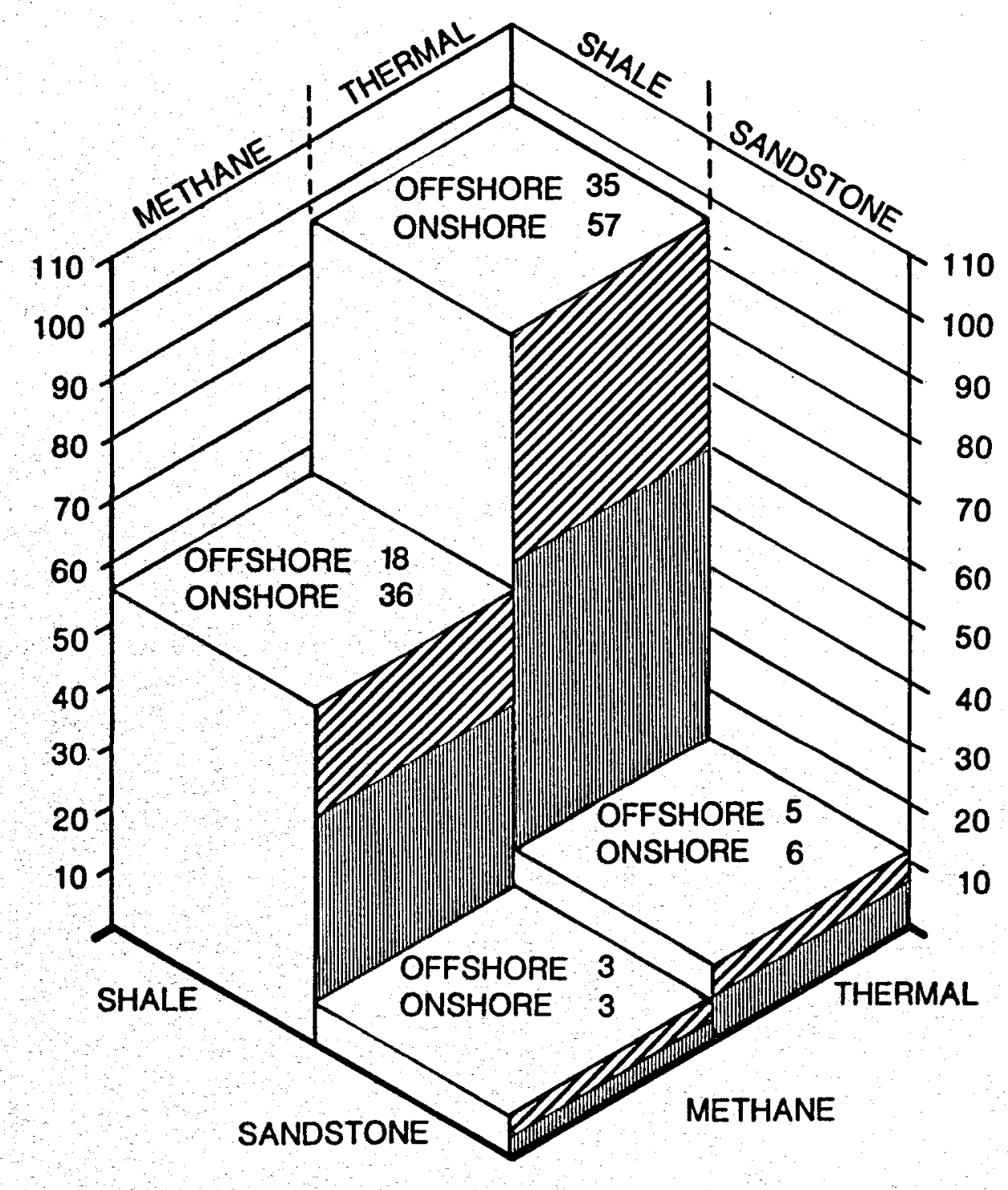

OFFSHORE

ONSHORE

SOURCE : Derived from U.S.G.S.

Circular 790 
are 6 and 3 thousand quads each (1 quad equals about 1 trillion cubic feet Tcf). These resources are the focus of the DOE Geopressure-Geothermal Program. In their assessment, "shale" was used to denote not only shales, but also other sediments of lower permeability, such as silty shales and shale siltstones: These are not part of the net effective sandstone formations, but are considered part of the total resource base. However, there is essentially no data available on the characteristics of these "shales." In addition, recovery of energy from these formations would be difficult because of their low permeability. Thus, the primary target for DOE's R\&D program is sandstones, because this is the lithology from which primary production is expected.

The geopressured sandstone formations beneath the onshore coastal areas of Texas and Louisiana are the sites of the initial tests because development and production costs are lower and more resource data is available. In addition, geologic studies have identified large fairways that may contain substantial quantities of water and dissolved methane because of their high pressures and temperatures and proximity to source rock, and the resource is reasonably close to existing pipelines and industrial centers.

Once the resource is proved onshore, the recovery techniques could be readily adapted to offshore areas.

Other geopressured areas have also been identified from the West Coast to Appalachia, Exhibit 1-5, and data is being gathered on these prospects.

\subsection{GEOPRESSURE-GEOTHERMAL RESOURCE DEVELOPMENT}

\subsubsection{Developing the Geopressure-Geothermal Resources}

The commercial development of geopressured aquifers will require production of large amounts of water which, in turn, will mean drilling somewhat larger diameter wellbores than are normally drilled for a gas well. Drilling into the geopressured zones often causes technical problems, and larger wellbores could add to the difficulties and risk. Recovering energy from the geopressured brines will also require modifying existing systems to produce, handle, and dispose of large volumes of hot, saline water. The specific technical issues involved in recovering the three forms of energy-chemical, thermal, and mechanical-from geopressured aquifers are summarized below:

- Chemical Energy. Currently, chemical energy in the form of methane is deemed to be the most important energy resource because of its high energy density and the presence of an existing infrastructure for transporting natural gas to markets from the Gulf Coast area. While geopressured aquifers have not yet been developed and produced, initial testing has shown that there are technical problems needing attention, dealing primarily with the handling of large volumes of saline fluids, scaling, corrosion, and the disposal of the produced brines.

- Thermal Energy. The Department of Energy's Hydrothermal Program addresses the use of geothermal energy for direct heating or for generating electric power. Assuming large volume, high temperature aquifers are found, it may be possible to generate power at costs comparable with the cost of electricity from new, fossil-fueled plants.

- Mechanical Energy. The third form of energy contained in geopressured aquifers is mechanical energy. Because of the relatively high flow rates, as much as 40,000 barrels per day, and the high well-head pressures from 2,500 to $6,000 \mathrm{psig}$, it may be possible to economically generate electricity for either onsite use or for distribution into a power grid.

\subsubsection{Total Energy Systems}

A potentially attractive future development would be integration of the recovery systems for the three forms of energy (chemical, thermal, and mechanical) into a total energy system. 
Exhibit 1-5

\section{GEOPRESSURED BASINS OF THE UNITED STATES}

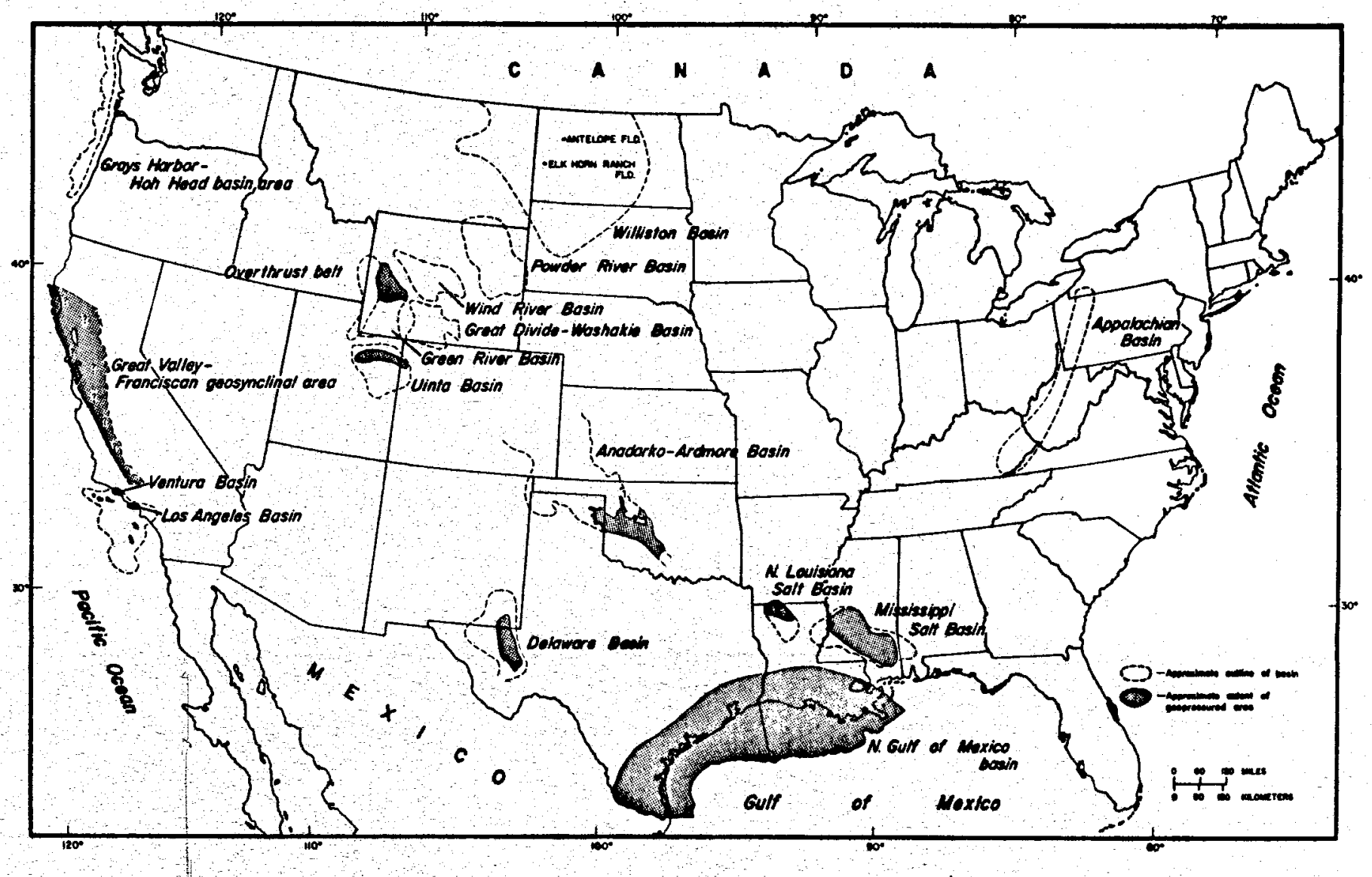

Source: U.S.G.S. Circular 790 
Conceptually, in a total energy recovery system, the geopressured water would first drive a turbine and deliver mechanical energy to produce electric power, Exhibit 1-6. The water would then be directed through a separator, where the methane would be extracted. Finally, thermal energy could be recovered by using a Rankine-binary cycle geothermal power plant in which the hot water evaporates a fluid in a closed secondary loop which is used to generate electric power. Thermal energy could also be used directly, such as for process heat or space heating, and in industrial applications, such as frozen food packaging, gasahol processing, and tertiary oil recovery. The geopressure-geothermal resource base underlying the Texas and Louisiana Gulf Coast is co-located with a broadly diversified industrial region. These manufacturers use a substantial part of their energy for generating steam at less than $390^{\circ} \mathrm{F}$, thus providing a potential market for direct use of the geothermal energy.

\subsection{NEED FOR A FEDERAL ROLE}

\subsubsection{Support of National Priorities}

To further the national objective of greater energy selfsufficiency, it is important that the technical and economic potential of the geopressure-geothermal resources be well understood. The information gathered from the initial R\&D is designed to establish the size, producibility, and environmental acceptability of these resources. There is an urgent need for this data to assist in determining the role of these energy resources versus other sources of natural gas and conventional energy. Given the urgency for this information and the limited private sector investment anticipated in the near-term, there is a need for the Federal Government to conduct the initial R\&D, gather data, and assess the resource potential. Should these resources compare favorably with other domestic energy options, the DOE will be in a position to formulate appropriate policies and incentives for subsequent commercial development by the private sector.

\subsubsection{Overcoming Historical Perceptions}

Although a large "in-place" methane and thermal resource base is acknowledged to be contained in geopressured aquifers, numerous historical perceptions limit industry's interest in pursuing them:

- Industry's drilling in search of oil and gas is normally in the onstructure part of reservoirs and near areas of structural confinement. The oil and gas reservoirs found in the highly faulted Gulf Coast area have thus been relatively small. By extension, it has been postulated that the geopressured aquifers would also be small. However, prospects for the geopressure resource are the much larger reservoir volumes offstructure which are normally not considered suitable by industry for oil and gas exploration.

- Industry's expectation from deep, expensive wells is a production rate of several million cubic feet of gas per day with limited production of water. In contrast, a favorable geopressured aquifer may produce less than two million cubic feet of gas per day along with large volumes ( 40,000 barrels per day) of saline brines. Thus, the current perception is that geopressured aquifers are marginal prospects in comparison with conventional gas exploration. However, as conventional gas becomes more difficult to find, the proper economic comparison may be with synthetic gas from coal or other unconventional gas sources.

- Uncertainties about subsidence, water disposal, mineral rights, and other environmental, legal, and socio-economic issues have relegated the resource to a high-risk status within industry.

Given the high front-end $R \& D$ costs required to better understand this resource, resolve the historical uncertainties and reduce the risks, no single company on its own has been willing to sponsor significant resource assessments and support basic research. Traditionally, the Federal role in R\&D has been to accept the high risks of funding unproven technologies and to gather sufficient and reliable information to overcome the historical perceptions that impede the development of unconventional resources. 
Exhibit 1-6

\section{FLOW DIAGRAM OF A TOTAL ENERGY SYSTEM}

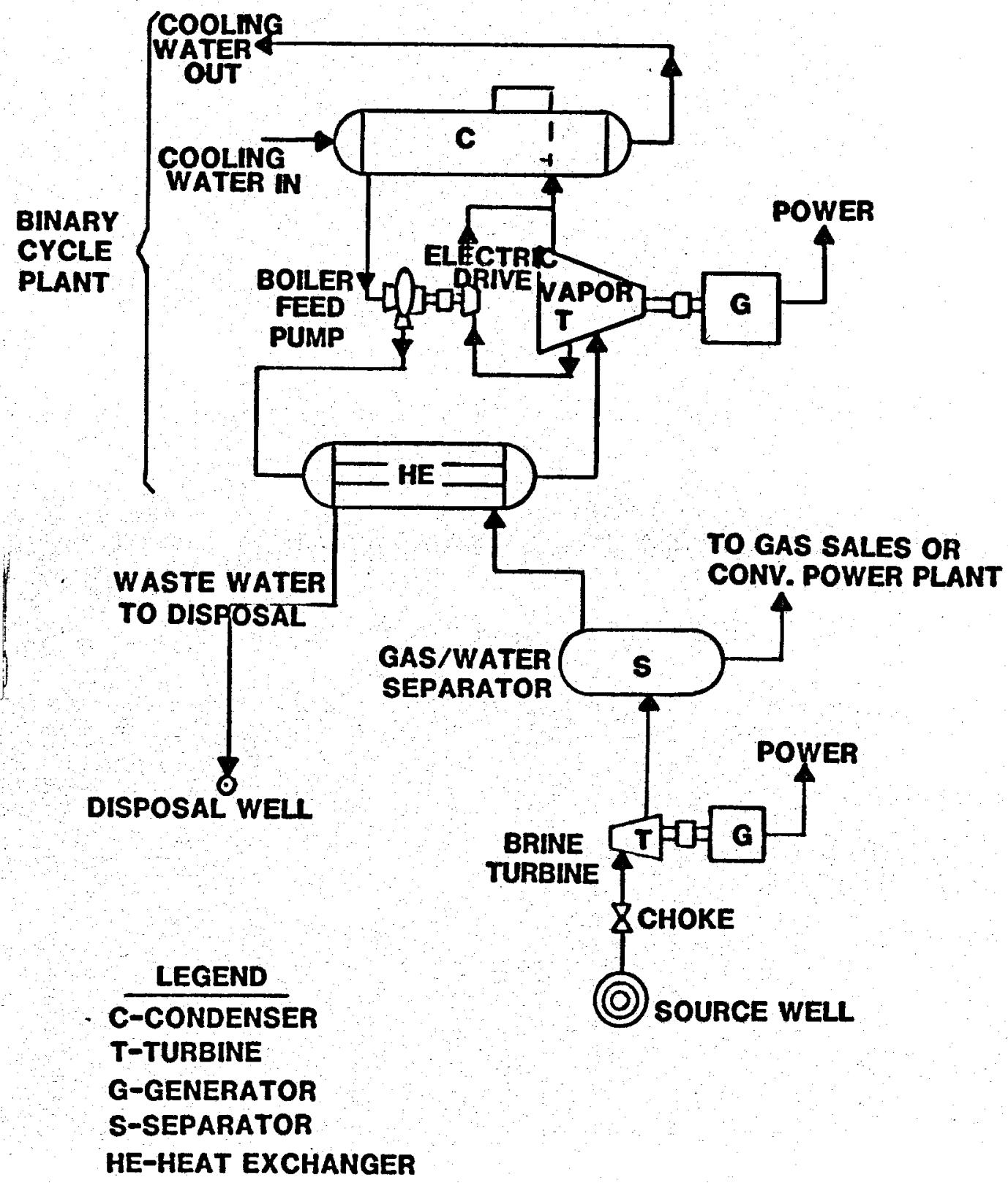




\subsubsection{Coordination of Federal and Private Sector Involvement}

Substantial opportunity exists for adapting technology developed in other areas, such as the technology being developed for extracting power from moderate temperature, $150^{\circ} \mathrm{C}$, fluids in the DOE Hydrothermal Program, and analyzing information available from industry, such as from wells drilled into geopressured zones. The timely collection and use of this information should be highly cost-effective and productive.

The DOE program is well coordinated with the efforts of other organizations. For example, the Gas Research Institute (GRI) has an R\&D program funded at \$1.6 million in 1980 and $\$ 2.8$ million in 1981. The USGS is responsible for resource assessment, and their program in 1980 is funded at $\$ 1.1$ million. The Institute of Gas Technology (IGT) serves as a contract research laboratory for DOE and GRI. It is involved in designing and evaluating the results of well tests and developing instrumentation. Other institutions, such as American Gas Association (AGA) and Electric Power Research Institute (EPRI), are interested in resource development for methane and electricity supplies, but have no active research programs at this time.

\subsection{PROGRAM RATIONALE}

\subsubsection{Legislative History}

Research, development, and demonstration of geopressure-geothermal resources were authorized by the Geothermal Energy Research, Development, and Demonstration Act of 1974, (PL93-410). In addition, recognizing the need to supplement the existing program with incentives, the National Energy Act (NEA) of 1978 and the National Gas Policy Act (NGPA) of 1978 provided a series of special provisions for geopressure wells including: (1) an additional investment tax credit of $10 \%$; (2) a depletion allowance of $10 \%$ for producing methane from geopressured aquifers and an additional $15 \%$ to $22 \%$ for the thermal energy; and, (3) deregulation of the price of methane from geopressured aquifers. However, these incentives have so far proved inadequate to spur development because of the uncertainties which exist for geopressure-geothermal resources.

\subsubsection{Program Objectives}

Since 1974 the Department of Energy and its predecessor agencies have had an R\&D program to determine the potential of geopressure-geothermal resources. The main purposes of this program are to narrow the range of uncertainties for these resources; to demonstrate whether the resources are economically recoverable; and, to ensure the timely development of these domestic energy sources if a potential is demonstrated.

For these purposes, the Department of Energy has established the following seven objectives:

1. Define the extent of geopressured reservoirs within the recoverable resource;

2. Determine the technical feasibility of reservoir development, including downhole, surface, and disposal technology;

3. Establish the economics of production from a statistically significant number of reservoirs;

4. Conduct supporting research on reservoir and fluid characteristics;

5. Identify and mitigate adverse environmental impacts;

6. Identify and resolve legal and institutional barriers; and,

7. Promote commercialization.

The results obtained in the R\&D program may also be of benefit to the understanding and development of other resources that require: (a) technology for producing and disposing of large volumes of water; (b) improved characterization of the geopressured zones; and, (c) downhole and surface technology to handle hot, saline brines. 


\subsubsection{Program Activities and Accomplishments}

Major steps have already been taken by DOE toward analyzing and understanding the geopressure-geothermal resources. Included in the activities are well testing, technology development, environmental research programs, and geopressure energy conferences.

In addition, regional resource assessments have been and are being made by the U.S. Geological Survey which has completed two assessments of the geopressure-geothermal resources. It published its first estimates in Circular 726 in 1975. Circular 790, published in 1979 , updated and expanded the earlier study and analyzed the resource, estimating the amount of methane and thermal energy in shale and sandstone, onshore and offshore, as shown previously on Exhibit 1-4.

Resource Definition.Complementing this work, a major DOE effort has been underway since 1974 at the University of Texas at Austin (UT) and Louisiana State University (LSU) to prepare state-wide definitions of the geopressure-geothermal resources of the Gulf Coast. This work has begun to define the geopressured fairways of Texas and Louisiana and to delineate favorable areas that can be developed as test sites for long-duration testing.

- Characterization of Texas Geopressured Fairways. Detailed mapping of the Frio, Wilcox, and Vicksburg Fairways has resulted in choosing the first test well site in Brazoria County, Texas. This work is continuing based on geologic and seismic studies. The two best Texas sites identified to date are shown on Exhibit 1-7.

- Identification of Louisiana Geopressured Prospects. Sixty-three candidate geopressured prospects were initially identified in Louisiana, based on analysis and interpretation of well log data, geologic information, and seismic surveys. Further study and cooperation with the USGS have identified eleven priority sites, shown on Exhibit 1-8.

In addition to the resource mapping, research such as compaction measurement and sandstone consolidation analysis is being conducted to define specific reservoir properties which will improve the ability to make quantitative estimates of reservoir producibility.

Well Testing. Two well testing programs are being undertaken to investigate the geopressure-geothermal resources.

- Wells of Opportunity. DOE monitors all oil and gas exploration drilling in Texas and Louisiana, since many of these wells penetrate geopressured aquifers. Those wells, which are unsuccessful and which meet specific criteria, are evaluated as candidates for recompletion and testing in geopressured reservoirs. While these Wells of Opportunity can be tested at lower cost, they are usually suitable only for shortterm testing to determine fluid characteristics and some reservoir parameters. However, a decision to extend the testing, based on the results, may be made prior to abandoning the well. Considerable information has been obtained from the Wells of Opportunity successfully tested to date.

- Design Wells. The second well program is designed to acquire information on all reservoir, fluid, production, and environmental parameters in favorable prospects identified from geologic studies. This is accomplished through long-term testing of wells drilled vertically to test the geopressured zones. As of mid-1980, DOE has seven Design Wells under contract; of these, one in Texas at Pleasant Bayou is being tested and one in Louisiana at Sweet Lake is being drilled.

Research and Development. In addition to the resource mapping and well drilling activities, research and development is being funded by DOE to help move technical, economic, and institutional barriers to commercialization of the resource:

- Aquifer Fluid Characterization. Two DOE projects are underway; one at Idaho State University to determine the solubility of methane and $\mathrm{CO}_{2}$ in water under varying conditions; and one at the University of Southern California to 
Exhibit 1-7

\section{TEXAS GEOPRESSURED FAIRWAYS AND PRIMARY PROSPECTS}






\section{Exhibit 1-8}

\section{LOUISIANA PRIORITY GEOPRESSURED PROSPECTS}

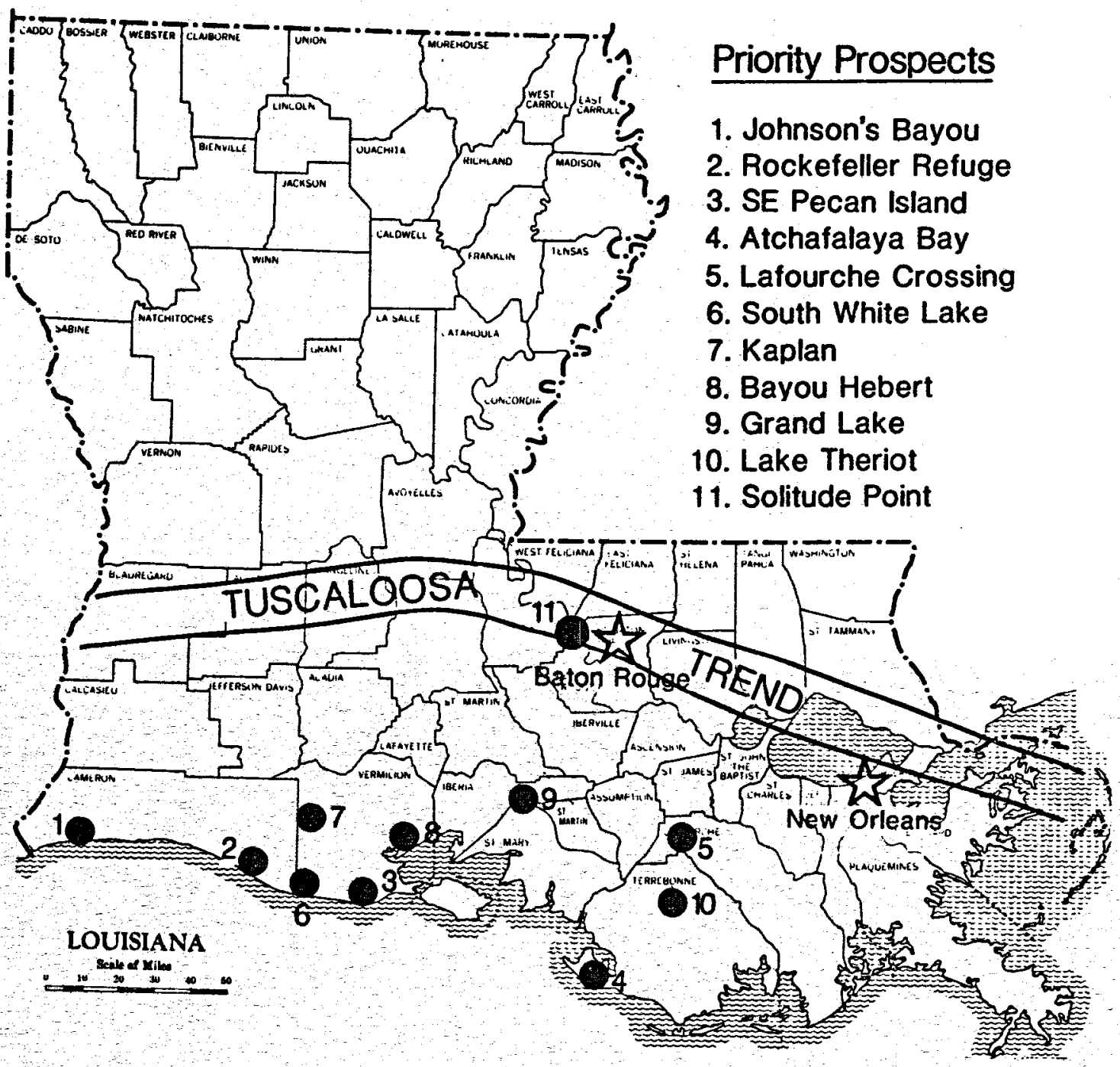


study whether the aquifer pressure can be drawn down enough to create free gas. The USGS is conducting a related study on the use of radioactive tracers to analyze the possibilities for shale dewatering, which could add considerable amounts of fluid to that producible from reservoirs of sandstone formations. In addition, the USGS is conducting a study on geochemical modelling to determine compatability of brines from producing reservoirs with waters in disposal formations.

- Data Processing. This support is provided in three major categories; (1) production and economics models to evaluate the resource potential (UT, IGT, and Systems, Science, and Software); (2) interpretation of test data, including calibration of models using historic data and prediction of production (IGT and Intercomp); (3) creation of an information system from digitized well logs (University of Texas).

- Legal, Institutional, and Operations Research. Since geopressured aquifer production is untried, nontechnical factors that affect development need to be identified and resolved concurrently with technology development. Legal studies have been made for Texas and Louisiana, and operations research was funded at the University of Texas and Louisiana State University to produce conceptual development plans for the geopressured resource.

Environmental Studies. Preliminary investigations indicate subsidence and water disposal are areas of primary concern in producing geopressured aquifers. These concerns will be monitored separately at each Design Well site. Efforts are underway in Texas and Louisiana to environmentally qualify potential well sites for aquifer development. Investigations have taken the form of both general and site-specific analyses.

\subsubsection{Program Priorities}

To attain its objectives the $R \& D$ program has been organized according to the following priorities:

- Near-Term Priorities (FY1981-82). Preliminary Definition of the Resource. By the end of FY82, sufficient data will have been gathered from geologic studies, from industry, and from DOE well tests, so that a preliminary confirmation of the size and technical viability of the resource is feasible.

- Mid-Term Priorities (FY1983-86). Assessment of the Resource Potential. By the end of FY86, enough data will be available to conduct an assessment of the economic and technical recoverability of energy from the geopressure-geothermal resources. Appropriate downhole and surface technology will have been selected or developed. Advanced recovery technologies will be available from the Hydrothermal Program for adaptation. Substantial progress will also have been made toward resolving or mitigating environmental, legal, social, and institutional constraints.

- Long-Term Priorities (Beyond 1986). Commercialization and Total Energy Systems. After FY86 it is expected that industry will develop the potential resource. DOE will assist this development by working to resolve constraints that might impede the effort and by developing technology for extracting mechanical and thermal energy to provide a total energy system, including the design and construction of a pilot plant, if warranted.

\subsubsection{Implementation Strategy}

The implementation strategy of the Geopressure-Geothermal Program is organized around three activities, as shown on Exhibit 1-9.

Activity 1. Resource Definition. The purpose of this activity is to establish the location, number, and size of potentially producible geopressured aquifers.

Three major areas are to be pursued by DOE for resource definition:

- Geologic Studies. Conduct regional geological appraisals of the resource to establish location, geological setting, and reservoir parameters. Extrapolate these findings to estimate the total number and extent of producible geopressured aquifers. 
Activity 3. Environmental Studies. The primary purpose of this activity is to anticipate, understand, and develop methods to control any environmental problems associated with development of the geopressure-geothermal resources.

The two main components of the activity are:

- Prospect-Specific Activities. This work focuses on individual development sites and includes regional baseline studies, environmental data collection and analyses of the environmental impact of site development, and monitoring of the environment at the site.

- Generic Activities. The environmental consequences addressed by the generic activities are expected to be observed at all sites where development is undertaken and include the issues of subsidence, release of toxic gasses, and disposal of the spent brine.

\subsubsection{Major Program Milestones}

The program schedule and major milestones are shown on Exhibit 1-10.

A major milestone has been scheduled for the end of FY82. By then the geologic studies and the testing of the first 12 Wells of Opportunity and 5 Design Wells should have produced detailed reservoir data. The results from these production tests and critical R\&D projects will provide the initial insight into the technical feasibility of developing the resource. These data will be sufficient to allow a thorough reevaluation of the program and a restructuring, if warranted.

A second milestone occurs in FY86 when the data from the 24 Wells of Opportunity and 12 Design Wells have been gathered and evaluated. By then, sufficient data will have been collected to allow a comprehensive assessment of the potential of geopressure-geothermal energy.

- Wells of Opportunity. Conduct a program of short-term tests of fluid and near-wellbore reservoir properties using wells drilled by industry.

- Design Wells. Drill a limited number of wells in prime selected prospects and conduct long-term tests to determine reservoir limits, production mechanisms, and environmental parameters in favorable geopressured fairways.

This activity is complemented by the overall resource assessment being conducted by the USGS.

Activity 2. Demonstration of Recovery Potential. The purpose of the second activity is to adapt or develop the required production technology, develop new gas separation technology, and investigate opportunities for local use of the geothermal resource. Three major areas will be pursued:

- Recovery Technology. Adapt or develop recovery technology suitable to the high pressures and high temperatures associated with the geopressure-geothermal resources. Develop the technology needed for efficient extraction of chemical, thermal, and mechanical energy from the brines.

- Supporting Research. Conduct laboratory studies and use numerical models to improve the scientific and engineering understanding of the reservoir characteristics and production mechanisms.

- Development Constraints. Advance the use of the geopressure-geothermal resources by identifying interested local and state organizations and helping them resolve their constraints. 


\section{Exhibit 1-10}

\section{MAJOR MILESTONES FOR ASSESSMENT OF RESOURCE POTENTIAL}






\section{CHAPTER 2.0 TECHNICAL PROGRAM}

\subsection{INTRODUCTION}

The emphasis of the Department of Energy's Technical Program for geopressure-geothermal resources is on defining the location and size of potentially producible resources and on developing technologies for extracting the energy from them in an economically feasible and environmentally safe manner.

The first two activities, Resource Definition and Demonstration of Recovery Potential, are conducted in parallel. The relationship between their objectives, purposes, and implementation are shown on Exhibit 2-1.

The first activity, Resource Definition, will define the location and extent of geopressured aquifers in conjunction with the regional resource assessment activities being conducted by the USGS. The DOE is responsible for conducting geologic studies in Texas and Louisiana and for conducting well testing programs designed to provide information on resource characteristics and produce detailed reservoir and fluid data from the most favorable identified sites.

The second activity, Demonstration of Recovery Potential, will establish the economic and technical feasibility of producing geopressured aquifers. The technology for developing the aquifers will be adapted and refined during the two well testing programs using recovery technology developed by the oil and gas industry. At the same time, laboratory and modelling studies will be conducted to better define the characteristics of the aquifers. Institutional and other constraints on development of the resources will also be addressed under this activity.

Thus, the first activity will define the location and magnitude of the potentially producible geopressure-geothermal resources and the feasibility of producing them. The second activity will assist in the development of recovery technology, improvement of the technical understanding of the resource, and resolution of development constraints.

Milestones for the technical program are shown on Exhibit 2-2. A major milestone is indicated at the end of fiscal year 1982. By then, the geologic studies and initial results from the Design Well and Wells of Opportunity programs will be available to indicate the extent and magnitude of the producible resources, the production characteristics of the most favorable identified areas, and the fluid and reservoir characteristics in these areas. This information, together with the results of the initial R\&D, should provide a thorough preliminary assessment of the resource potential including an evaluation of the program.

The second major milestone is at the end of fiscal year 1986. By then 24 Wells of Opportunity and 12 Design Wells will have been tested. This is considered a statistically significant number of wells and the data should provide sufficient information to evaluate the resource potential when complemented by the results of Activity 2, Demonstration of Recovery Potential. 


\section{Exhibit 2-1}

\section{TECHNICAL PROGRAM ACTIVITIES}

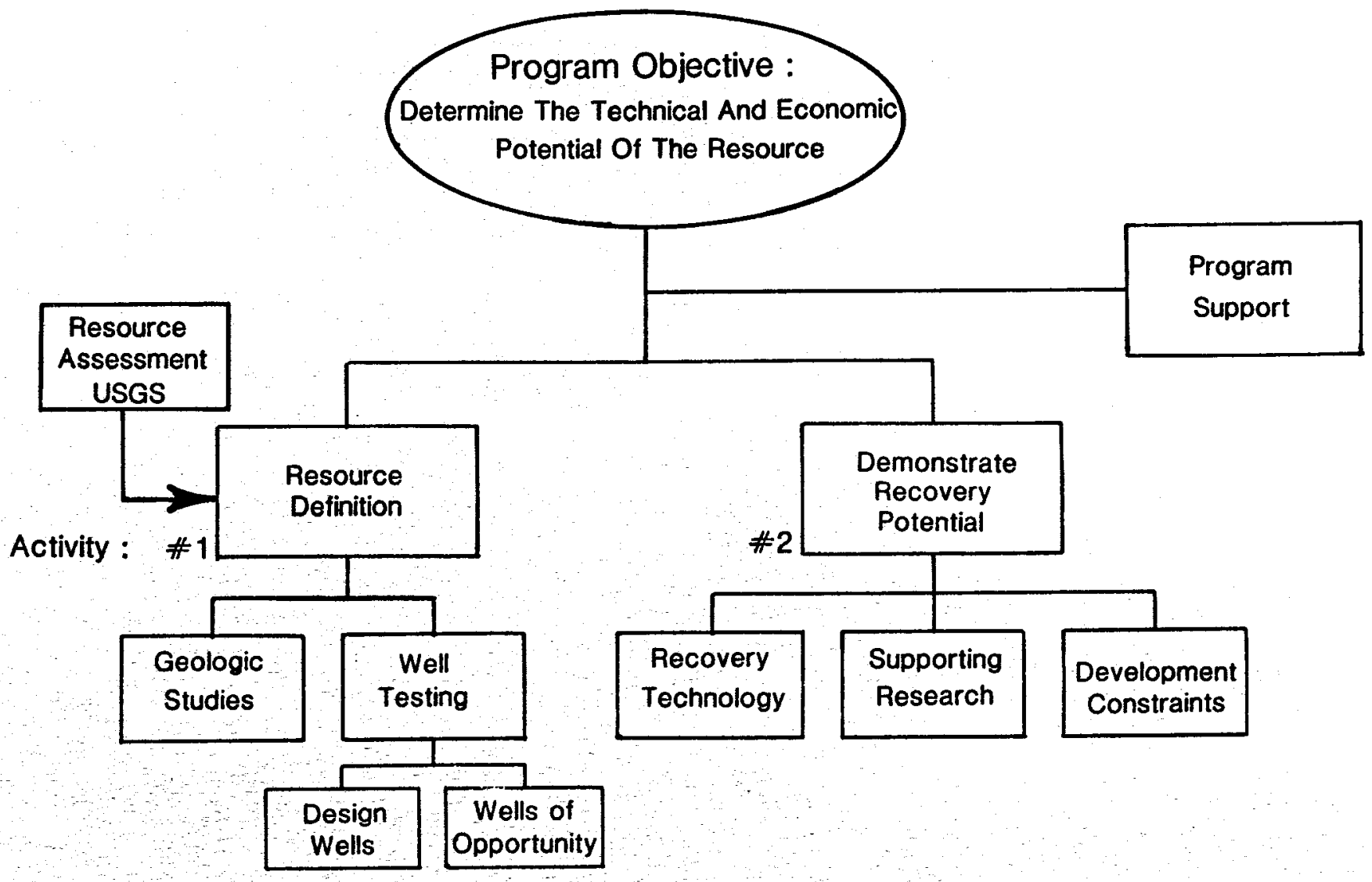

Purpose:- Define the Geopressure-
Geothermal Resources

Implementation : Regional Geologic Studies

Conduct Well Testing Programs
Establish the Economic and Technical Feasibility of Producing Aquifers

Adapt and Refine Existing Recovery Technology

Conduct Laboratory and Modeling Studies as Supporting Research

Resolve Constraints 


\section{Exhibit 2-2}

\section{MILESTONES FOR ASSESSMENT OF RESOURCE POTENTIAL}

1 RESOUACE DEFINITION Goologic Studies

Well Testing

Design Wells

Pleasant Bayou

Sweet Lake

Dow Sweezy *1

Gladys McCall $\# 2$

Lafourche Crossing

Design Well $\quad 6$ (Unidentified, Under Contract)

Design Well *7 (Unidentifled, Under Contract)

Design Well $* 8$

Design Well *9

Design Well *10

Design Well *11

Design Well * 12

Wells of Opportunity Well of Opportunity Well of Opportunity Well of Opportunity

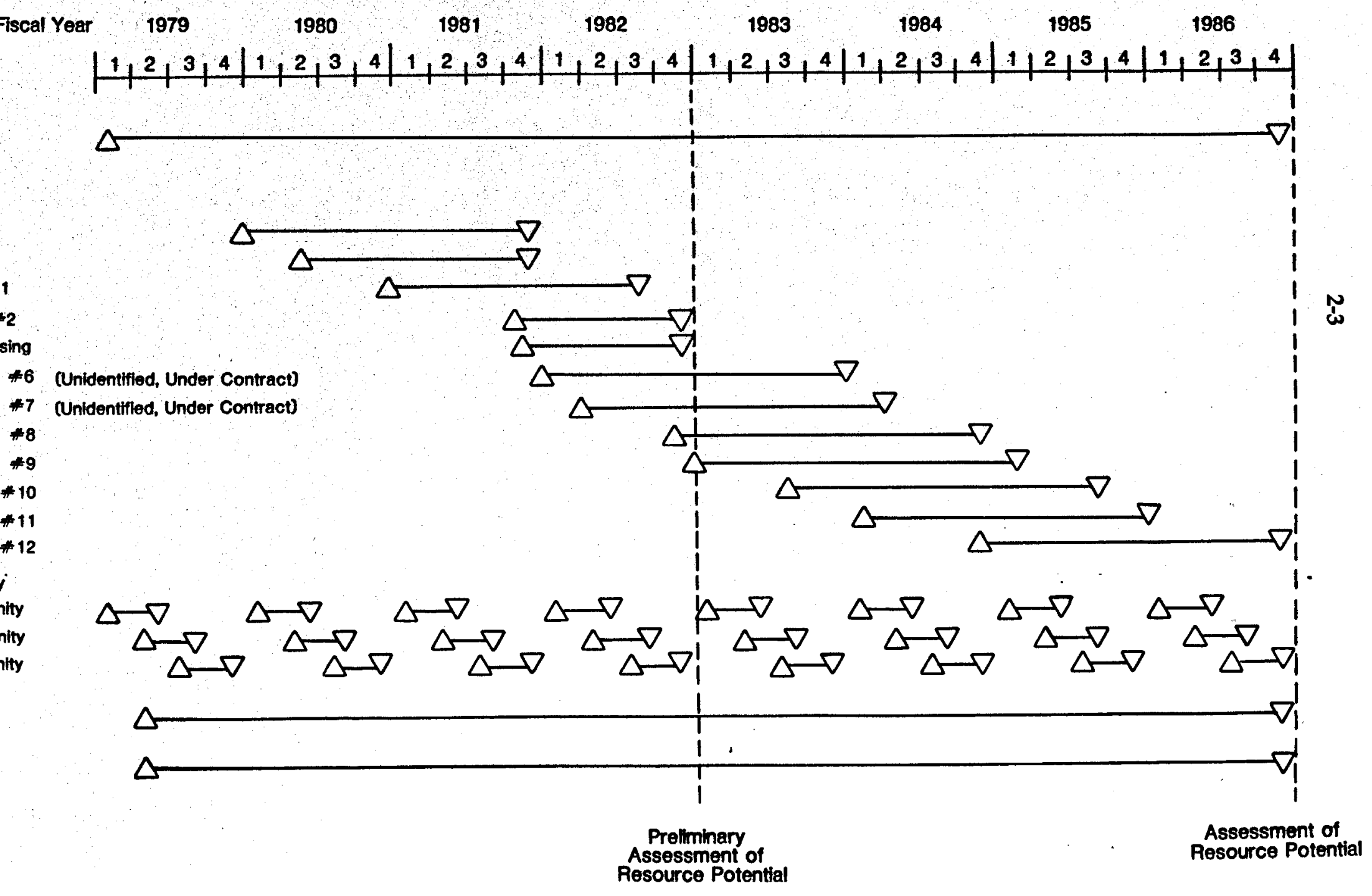




\subsection{DETAILS OF THE TECHNICAL PROGRAM}

\subsubsection{Activity 1. Resource Definition}

\subsubsection{Purpose}

Although the geopressure-geothermal resource base is large, too little reservoir and production data are available to reliably estimate the technical or economic potential of the geopressured aquifers that constitute this resource base. The purpose of Resource Definition, the first technical program activity, is to establish the location and size of the aquifers by conducting geologic studies and well tests to build a base of engineering and geologic data by the end of FY86. This activity will reduce the uncertainty associated with the size and nature of the recoverable resource and will establish the location of aquifers suitable for development.

Data on the aquifers will be gathered on an ongoing basis from the Wells of Opportunity and the Design Well programs. This data will be used to better understand the resource and to verify the methodology used in selecting well sites.

\subsubsection{Approach}

The Resource Definition activity is further detailed on Exhibit 2-3. Data on the resource will be acquired by:

- Geologic Studies. Regional geologic studies will be conducted by industry and universities.

- Well Testing. Key reservoir and fluid data will be obtained from specific sites, either from industry or from the DOE sponsored Wells of Opportunity and Design Well programs.

Resource Definition is carried out in conjunction with the USGS, which is responsible for the regional resource assessment of the geopressure-geothermal resources. The USGS has previously published two assessments and is continuing this work. The current focus of the USGS's activities is to provide estimates of the recoverable resource based on the results of the DOE well tests and information developed independently by the USGS. It is also involved in:

- advising the DOE on well sites proposed for testing;

- radioactive tracer studies to determine whether there is shale dewatering when aquifers are produced;

- characterizing geopressured formations; and

- geochemical modelling to determine compatibility of the produced brines with the waters of disposal formations.

The DOE program maintains close contact with industry to ensure an efficient transfer of information, although only limited data has previously been collected by industry on the geopressure-geothermal resources. These contacts with DOE have, with some success, interested industry in collecting these data, particularly fluid samples from well tests in the geopressured zones.

\subsubsection{Discussion of Activity Components}

\section{Geologic Studies}

This work consists of regional geological and geophysical studies of all known onshore geopressure-geothermal resources in Texas (Frio, Vicksburg, and Wilcox) and Louisiana (Miocene, Oligocene, and Tuscaloosa) to delineate optimum areas for reservoir drilling and testing. The objective is to obtain data on the size and the location of aquifers that appear producible. 


\section{Exhibit 2-3}

\section{RESOURCE DEFINITION ACTIVITY}

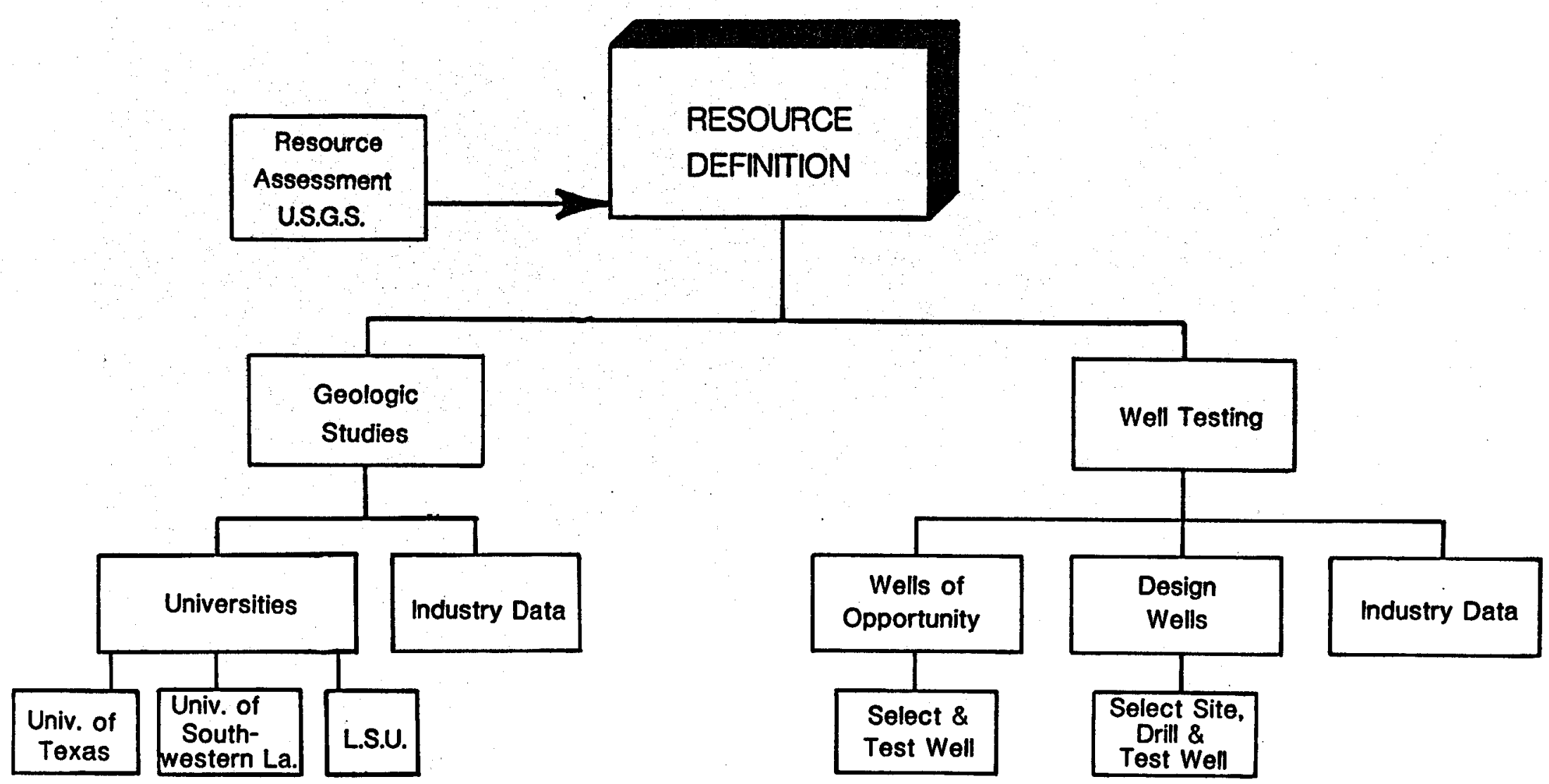

Purpose : Prepare Resource Definition of U.S. Gulf Coast

Implementation : Detailed Geologic and Geophysical Studies of the Texas and Louisiana Gulf Coast to Identify Fairways and Favorable Prospects
Collect Site Specific Reservoir and Fluid Data from Aquifers

Obtain Wells Drilled by Industry for Short-Term Testing and Drill Wells in Best Locations for Long-Term Testing 
Geologic studies include cooperation with the U.S. Geological Survey on overall resource assessment and funding of geologic studies at the University of Texas and Louisiana State University for resource definition.

a) University of Texas

Detailed resource definition for the Texas Gulf Coast area is being conducted by the Bureau of Economic geology of the University of Texas at Austin. The primary objectives are to define the geopressured fairways in the Texas Gulf Coast and to delineate favorable areas which could be developed as test sites for long duration (Design Well) testing. In the course of this work, well log information, geologic data, well production information, and seismic survey results are being integrated to define geopressured fairways based on criteria such as reservoir volume, temperature, pressure, porosity, permeability, and salinity. The Bureau has produced individual reports for the Vicksburg, Wilcox, and Frio formations in South Texas.

This work has resulted in choosing a site for the first Design Well in Brazoria County, Texas, and has delineated additional sites for consideration in drilling future Design Wells in the Frio and Wilcox formations. Continuing work centers around high-resolution seismic studies of other prospective sites in the Frio and Wilcox Fairways, Exhibit 1-7.

b) Louisiana State University

Resource definition in Louisiana is conducted by the Louisiana State University and Louisiana State Geological Survey. The purpose of this work is to define geopressured prospects and delineate favorable geopressured reservoirs which can be developed for long-term testing. Initial analysis and interpretation of well log data, geologic information, and seismic surveys have resulted in a list of 63 candidate areas. As a result of this and related work by the USGS, the eleven prospects shown on Exhibit 1-8 have been studied in detail, including a promising site in the Tuscaloosa Trend. Current work is aimed toward building regional cross-sections through South Louisiana, with as many as possible going through the site areas to provide predictive capacity away from the sites.

\section{Well Testing}

The Wells of Opportunity and Design Well programs are two well testing programs designed to provide data on reservoir and fluid properties and to aid in assessing the magnitude and potential of the resource on the Gulf Coast. An outline of particulars associated with the two methods of providing reservoir data are summarized on Exhibit $2-4$.

a) Wells of Opportunity

Wells of Opportunity are wells that industry has drilled into or through geopressured reservoirs in the search for oil and gas and that are made available for testing. The advantage of using these wells for short-term tests of geopressured zones is that they allow DOE to obtain valuable information at a cost considerably below that of Design Wells. The disadvantage is that these wells are often drilled on-structure or near structural closure for entrapment of hydrocarbons; accordingly, they may not be in the most favorable locations for testing high volume delivery of aquifers. The testing provides information on important properties of the reservoir fluids (e.g., salinity, water chemistry, gas chemistry, and gas-to-water ratios) and the reservoir characteristics around the wellbore. While selected wells could be used for long-term testing, the tubing size and reservoir size of most do not justify long tests. However, the extent of testing is determined on a well-specific basis.

Plans include tests of three to four Wells of Opportunity per year for each of the next four years. Efforts will be made to select wells from the prime prospect fairways of Texas and Louisiana which include the Wilcox and Frio formations in Texas and the Tuscaloosa and Tertiary formations in Louisiana. Of the 12 to 16 Wells of Opportunity planned for 
Exhibit 2-4

PARTICULARS OF DOE'S TWO WELL-TESTING PROGRAMS

\begin{tabular}{|c|c|c|c|c|c|}
\hline & Locations & Costs & Test Duration & Availability & Testing \\
\hline $\begin{array}{l}\text { WELLS OF OPPOR } \\
\text { Oil/gas wells } \\
\text { completed in } \\
\text { geopressured } \\
\text { reservoirs }\end{array}$ & $\begin{array}{l}\text { UNITY } \\
\text { Usually } \\
\text { less than } \\
\text { optimum }\end{array}$ & $\$ 1.5-\$ 2.5$ million & $\begin{array}{l}\text { Usually } \\
\text { short-term } \\
\text { (2 weeks) }\end{array}$ & Early & $\begin{array}{l}\text { Limited: } \\
\text { fluid properties and } \\
\text { reservoir characteristics } \\
\text { around wellbore }\end{array}$ \\
\hline $\begin{array}{l}\text { DESIGN WELLS } \\
\text { Wells drilled in the } \\
\text { most favorable } \\
\text { identified aquifers }\end{array}$ & $\begin{array}{l}\text { Most Optimum } \\
\text { identified }\end{array}$ & $\$ 10-12$ million & $\begin{array}{l}\text { Long-term } \\
\text { (0.5-2 years) }\end{array}$ & $\begin{array}{l}\text { Longer } \\
\text { start-up }\end{array}$ & $\begin{array}{l}\text { Complete: } \\
\text { fluid properties, reservoir } \\
\text { characteristics, drive } \\
\text { mechanisms, and } \\
\text { reservoir limits }\end{array}$ \\
\hline
\end{tabular}


the next four years, well selection will be made with the intent of sampling the following depositional systems:

- Eocene Lower Wilcox and later Tertiary Sediments in Louisiana:

-High constructive delta depositional systems containing well developed and extensive constructional sequences with thick delta plain deposits.

-Fluvial sand deposits, updip from delta deposits, consisting of sand bodies made up of several coalescing channel lag, lower point bar, and chute front deposits, accumulated as multilateral, coarse-grained meander belt units up to 30 miles in width and up to 200 feet thick.

-Downdip delta front sand deposits at the terminus of distributary channels. Progradational sequences marked by upward coarsening and increasing sand content units accumulated as distributary mouth bars.

- Oligocene Frio of Texas and Frio equivalent and later Tertiary deposits of Louisiana:

-Wave dominated delta systems with associated fluvial and marine systems where the regional distribution of sands is similar to large barrier bar systems. Deposits commonly associated with strand plain and coastal barrier systems.

- Upper Cretaceous Tuscaloosa formation deposits of Louisiana:

- "Downdip" Tuscaloosa sandstone deposited south of the Edwards reef edge on the continental slope, sandstone deposits on the shelf, and submarine fans on the shelf slope. The southward thickening wedge of sediments formed with concurrent faulting that created structural traps wherein the downthrown growth fault blocks have accumulated more deposits than the upthrown side and are geopressured.

Seven Wells of Opportunity were tested through the Fall of 1980 in Louisiana. Their locations are shown on Exhibit 2-5. In addition, two wells were tested in Texas, Exhibit 2-6. The primary selection criteria for Wells of Opportunity are shown on Exhibit 2-7.

While the initial data from these tests indicated that the geopressured fluids are often saturated with methane, some indicated that the waters were saline and contained $\mathrm{CO}_{2}$, leading to lower methane content and scaling. However, the number of wells is still too few to provide significant data on the numerous reservoir properties associated with geopressured aquifers.

In order that the data acquisition under the Wells of Opportunity Program can be coordinated, minimum standards for chemical sampling and analyses for future tests are being developed by McNeese State University under funding provided by GRI, and standards for coring and core analysis are being developed by the Bureau of Economic Geology at the University of Texas at Austin.

A brief account of the nine well tests completed as of Fall 1980 is given below. The well test data is summarized on Exhibit 2-8 for the six wells where testing was completed successfully.

- The Edna Delcambre Well in Tigre Lagoon, in Vermilion Parish, Louisiana, was the first well test of geopressured aquifers and evaluated the water and gas production from two sands. Initially, the gas flow was equivalent to the solution ratio of about 20 standard cubic feet ( $\mathrm{scf}$ ) per barrel of water. However, subsequently the gas ratio increased to 50 to 60 scf per barrel of water. Reservoir modelling shows that production or coning of free gas from adjacent reservoirs can account for the excess gas.

- The Alice C. Plantation No. 2 in St. Mary's Parish, Louisiana was selected as the second test well from among a number of reentry candidates. This well was originally drilled in 1964 to a total depth of 19,000 feet and was plugged and abandoned after it was found to be unproductive. Preparation for reentry began in July 1978, and the well was cleaned out to a depth of 18,000 feet. The reentry attempt was unsuccessful and the test was abandoned. 


\section{Exhibit 2-5}

\section{LOCATION OF DOE LOUISIANA WELLS OF OPPORTUNITY}

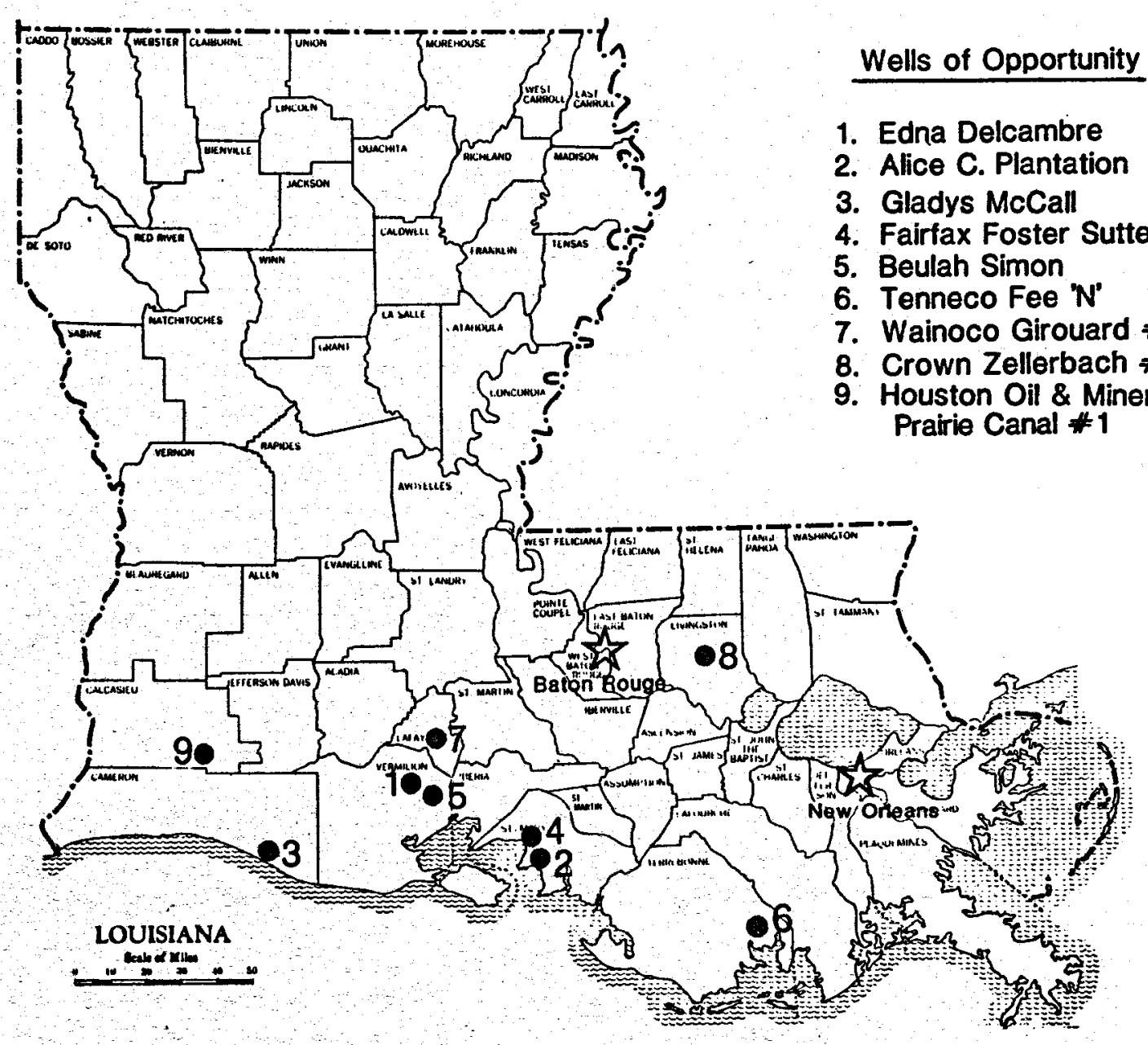

Copyright, Amorican Map Co. Inc., Now York, No. 18568 
Exhibit 2-6

\section{LOCATION OF DOE TEXAS WELLS OF OPPORTUNITY}



Copyright, American Map Co., Inc., New York, No. 18568 
Exhibit 2-7

\section{WELLS OF OPPORTUNITY SELECTION GUIDELINES}

Wells proposed to DOE as Wells of Opportunity are selected using the following criteria:

1. Bottom hole temperature greater than $275^{\circ} \mathrm{F}$ (flexible).

2. Pressure gradient of $0.8 \mathrm{psi} / \mathrm{ft}$ (flexible).

3. Salinity less than $75,000 \mathrm{ppm}$ tds.

4. Minimum of 100 essentially continuous net feet of $100 \%$ water saturated porous sand of good permeability, as determined by available well logs, and core data.

5. Readily accessible land site near optimum reservoir areas.

6. Reasonably continuous drainage area.

7. Adequate casing and completion to mechanically permit the desired test.

8. Some geographical dispersion of the test sites.

9. Adequate well logs and other geologic data.

10. Suitable financial arrangements.

11. Indication of adequate gas in solution.

- The Gladys McCall Well No. 1 in Cameron Parish, Louisiana, was originally drilled in 1965 to a depth of 15,598 feet and subsequently plugged and abandoned as a dry hole. After exhaustive and unsuccessful attempts at reentry, it was decided to plug and abandon this well.

- The Fairfax Foster Sutter Well No. 2 in St. Mary's Parish, Louisiana, was the first Well of Opportunity offered for testing immediately after the original operator determined it to be a dry hole. A short-term test showed a gas-water ratio of 22.8 cubic feet per barrel of water. The produced water was more saline than expected $(190,904 \mathrm{mg} / 1)$. High concentrations of dissolved solids and the $\mathrm{CO}_{2}$ content of the waters led to scaling problems in the tubulars and surface equipment.

- The Beulah Simon No. 2 Well in Vermilion Parish, Louisiana, was drilled to 15,300 feet and then offered to DOE for testing. Testing was conducted from September through December, 1979, after the well was recompleted at approximately 14,700 feet. The test data showed that the gas content was 24 standard cubic feet per barrel of water, and the salinity was $100,000 \mathrm{ppm}$. Gas content was about $89 \%$ methane.

- The Tenneco Fee "N" No. 1 Well was offered for testing in one geopressured zone. The well is located in Terrebonne Parish, Louisiana, and barge operations were necessary to test the well. After reentry, it was discovered that the casing leaked. Attempts to plug the leaks failed and the test was abandoned.

- The Wainoco P.R. Girouard No. 1 Well is located approximately 10 miles southeast of Lafayette, Louisiana. Flow tests were conducted for sustained production rates of approximately 4,000 to 18,500 barrels of water per day. Salinity of the produced water was low at $22,500 \mathrm{mg} / 1$. The gas to water ratio was relatively uniform at 37 to $39 \mathrm{scf} / \mathrm{bbl}$. Laboratory recombination studies indicate that the brine may not be fully saturated.

- The G.M. Koelemay No. 1 Well, located about 19 miles west of Beaumont, Texas, was flow tested over 20 days at production rates of 3,500 to 6,000 barrels of saline water per day. Water with as low a salinity of $15,000 \mathrm{mg} / 1 \mathrm{had}$ gas-to-water ratios of 35 to $39 \mathrm{scf} / \mathrm{bbl}$. Initial pressure of the reservoir at 11,540 feet was 9,382 psi and the temperature was $257^{\circ} \mathrm{F}$. During testing, an oil rim and gas cap was coned into the well from an updip entrapment area and the well was taken over by Lear Petroleum Exploration, Inc., after aquifer tests were completed. 


\section{Exhibit 2-8}

\section{SUMMARY OF WELLS OF OPPORTUNITY TEST DATA}

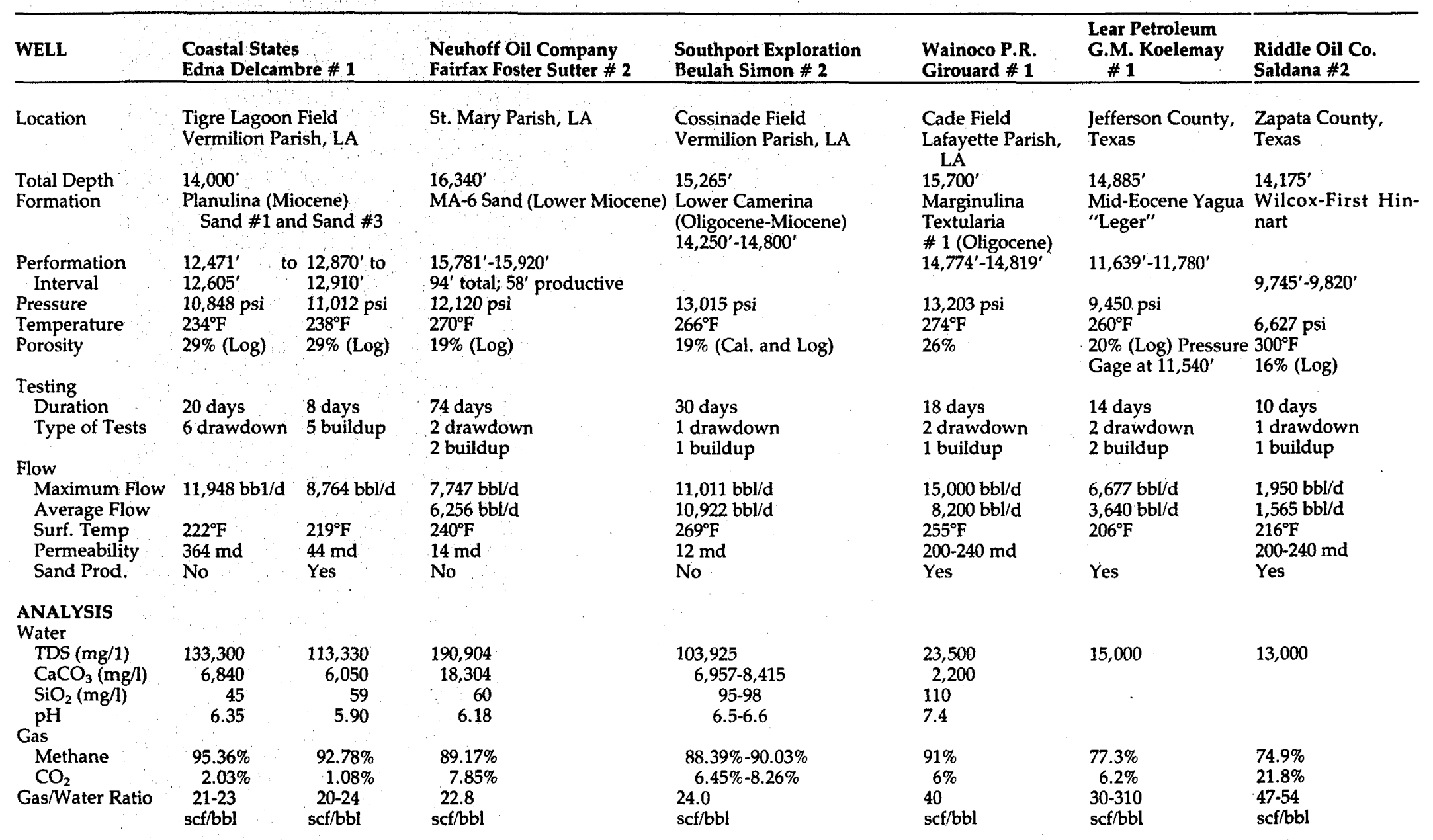


- The Riddle Saldana No. 2 is located approximately 60 miles east southeast of Laredo, Texas, in Zapata County. The highest flow rate tested was 1950 barrels of water per day from the Wilcox at a depth of about 9850 feet. The salinity of the water was low, $13,000 \mathrm{mg} / \mathrm{l}$, and the downhole temperature was high, $310^{\circ} \mathrm{F}$. Consequently, the gas-oil ratio was relatively high; it varied from 47 to $54 \mathrm{scf} / \mathrm{bbl}$. The gas also had a high $\mathrm{CO}_{2}$ content, ranging from $18.5 \%$ to $24 \%$.

Based on the experience of the two reentries into abandoned wells, it was decided not to reenter under similar conditions. Experience with the Tenneco well has also shown that barge operations raise costs significantly and create operating problems without necessarily providing better opportunities or data.

To adequately characterize the diverse geopressure-geothermal resource, future wells will be selected to test geological horizons that have not yet been examined. With industry's greater interest in the Geopressure-Geothermal Program, a larger sample of wells is now being offered, including in some instances, preliminary fluid samples to qualify the well for the Wells of Opportunity Program. Another possibility under discussion with DOE is to share the cost of a well drilled to produce water and gas from geopressured zones for local use. Under this arrangement, DOE would be allowed to test the well before it is put on production. Efforts are also underway to find companies interested in utilizing the energy supply at the end of the short-term testing period for such operations as gasahol plants, sugar refining, and paper mills.

It is anticipated that ultimately 24 Wells of Opportunity will be obtained and tested, at an average rate of three to four wells per year through FY86.

b) Design Wells

Design Wells are wells drilled on sites in potentially favorable geopressure-geothermal prospects as defined by the best available geological and geophysical data. Extensive work has been done by the Texas Bureau of Economic Geology to identify Texas fairways and prospects and by the Louisiana Geological Survey for Louisiana fairways and prospects using well log information, seismic survey results, and other available geologic data. Where seismic information is not available from service companies and oil companies, seismic survey lines are contracted for. This can provide information on subsurface structures and aid in selecting the most favorable well site to penetrate the maximum geopressured aquifer that is unbroken by growth faults.

Particulars of Design Wells were listed previously in Exhibit 2-4. Large volume reservoirs are required to enable the high cost Design Wells to answer crucial questions related to resource development, such as whether geopressured aquifers can be produced at high volume flow rates for the period of time required for acceptable economic returns. Typically, Design Wells will be flow-tested for approximately two years to determine reservoir deliverability and to ascertain other important aspects of resource development, including operation and evaluation of an integrated system for energy recovery and fluid disposal. Through such testing, strategies for optimum economic development of reservoirs can be identified and demonstrated, including monitoring of long-term environmental effects.

The extended duration tests to be carried out by the Design Well program allow the reservoir fluid composition, reservoir characteristics, and drive mechanisms to be extensively tested. The latter two properties are usually not obtained from the short-term Wells of Opportunity tests. The intent of the Design Well program is to test a statistically significant number of the best identified prospects to determine the following parameters:

- Reservoir permeability, porosity, thickness, rock properties, depth, temperature, and pressure.

- Reservoir fluid content, salinity viscosity, and inert gasses and hydrocarbons in solution.

- Reservoir fluid production rates, pressure, temperature, and possible sand production. 
Exhibit 2-9

\section{SELECTION GUIDELINES FOR FAVORABLE RESERVOIRS}

- Reservoir volume - at least one cubic mile, with good thickness

- Fluid temperature - greater than $275^{\circ} \mathrm{F}$

- Minimum permeability - 20 millidarcys

- Water salinity - less than $50,000 \mathrm{mg} / 1$

- Initial bottom-hole pressure - greater than 0.7 psi per foot

- Production rate - capable of 40,000 barrels of water per day

- Equipment design for energy extraction and effluent disposal.

- Environmental factors, such as brine disposal, reservoir compaction, surface subsidence, and fault activation.

Testing of various surface components to determine the most efficient means of extracting thermal and mechanical energy from the aquifers is also planned. Initial guidelines for selecting favorable geopressure-geothermal Design Well sites are shown in Exhibit 2-9. These criteria are continually reviewed as new information on reservoir characteristics are obtained.

Design Wells will be drilled in the most favorable fairways and prospects in the Tertiary and Cretaceous (Tuscaloosa) trends in Louisiana and the Wilcox and Frio formations in Texas. Included will be reservoirs associated with:

1. High-constructive delta systems.

2. High-destructive delta systems.

3. Structural associations including reservoirs related to contemporary growth faults and reservoirs of specific delta facies related to regional and local structures.

Other prospects have also been and are being examined by the resource definition groups to define the most favorable sites.

Exhibit 2-10 summarizes data for three Design Well tests that are currently in progress. Exhibit 2-11 presents the preliminary data on two additional Design Well test under consideration in Louisiana. The program to date on the five Design Wells is summarized below:

- Pleasant Bayou. The test well is located in Brazoria County, Texas, Exhibit 1-7. Site selection was based on geologic studies conducted at the University of Texas. The well was started in January 1979 and completed in June 1979. Four zones were perforated and initially drill-stem tested. Production from these zones varied from 3 to 14 barrels of water per hour. A test zone from 14,644 feet to 14,704 feet was perforated and another well was completed as a disposal well. Results of a 10-day flow test, completed in December 1979, are summarized on Exhibit 2-10. Testing continues on this well.

- Sweet Lake, Louisiana. Magma Gulf Technadril has a contract to drill and test a geopressured well in Cameron Parish. Geologic studies of the area have been supplemented with seismic and the most promising well site has been identified. The target sand is in the Miogyp zone with a net sand thickness of 400 to 500 feet. Overlying sands at 7,000 to 8,000 feet will be used for testing the disposal of the produced brines. 


\section{Exhibit 2-10}

\section{DESIGN WELL TESTS - IN PROCESS}

\begin{tabular}{|c|c|c|c|}
\hline WELL & $\begin{array}{l}\text { Pleasant Bayou \# } 2 \\
\text { Fenix \& Scisson - DOE }\end{array}$ & $\begin{array}{c}\text { Sweet Lake \# 1 } \\
\text { Magma Gulf - Technadril - DOE }\end{array}$ & $\begin{array}{l}\text { Sweezy \# } 1 \\
\text { Dow Chemical - DOE }\end{array}$ \\
\hline $\begin{array}{l}\text { LOCATION } \\
\text { DEPTH } \\
\text { FORMATION(S) } \\
\text { NET THICKNESS } \\
\text { POROSITY } \\
\text { TEMPERATURE } \\
\text { PRESSURE } \\
\text { SALINITY } \\
\text { GAS WATER RATIO } \\
\text { DRAINAGE AREA } \\
\text { PRODUCTION RATE } \\
\text { DISPOSAL AQUIFERS } \\
\text { DURATION: CONTRACT } \\
\text { REMARKS TESTING }\end{array}$ & $\begin{array}{l}\text { Brazoria County, TX } \\
16,500^{\prime} \\
\text { Frio, T-5 Zone } \\
\text { (Oligocene) } \\
60^{\prime} \\
19 \% \text { (Log) } \\
280^{\circ} \mathrm{F} \\
11,050 \mathrm{psi} \\
131,320 \mathrm{mg} / 1 \\
20-25 \mathrm{scf} / \mathrm{bbl} \\
- \\
35 \text { months } \\
\text { Tested } 20 \text { days } \\
10 \text { day drawdown, } \\
10 \text { day buildup, } \\
\text { Avg. flow; } 13,500 \mathrm{bbV} \mathrm{d}\end{array}$ & $\begin{array}{l}\text { Sweet Lake Area, } \\
\text { Cameron Parish, Louisiana } \\
15,600^{\prime} \\
\text { Camerina Miogyp Sand } \\
\text { (Upper Frio) } \\
400^{\prime} \\
20 \% \\
310^{\circ} \mathrm{F} \\
10,100 \mathrm{psi} \\
46,000-100,000 \mathrm{mg} / \mathrm{l} \\
35-40 \mathrm{scf} / \mathrm{bbl} \\
12 \mathrm{mi}^{2} \\
40,000 \text { bbl/d } \\
6,410^{\prime}-7,345^{\prime} \\
26 \mathrm{months} \\
20 \mathrm{months} \\
\text { Long duration high volume } \\
\text { flow tests for gas sat., fluid } \\
\text { properties, reservoir delivera- } \\
\text { bility and resource economics. } \\
\text { Currently drilling. }\end{array}$ & $\begin{array}{l}\text { Parcperdue Area, Vermilion Parish } \\
\text { Louisiana } \\
13,600^{\prime} \\
\text { Cibicides Jeffersonensis Zone } \\
\text { (Frio) } \\
50^{\prime} \\
29 \% \\
220^{\circ} \mathrm{F}-235^{\circ} \mathrm{F} \\
12,000 \mathrm{psi} \\
90,000 \mathrm{mg} / \mathrm{l} \\
23 \mathrm{scf} / \mathrm{bbl} \\
10 \mathrm{mi}^{2} \\
25,000 \mathrm{bbl} / \mathrm{d} \\
4,725^{\prime}-4,635^{\prime} \\
24 \mathrm{months}^{\prime} \\
9 \mathrm{months} \\
\text { Same as Sweet Lake, plus } \\
\text { reservoir depletion for } \\
\text { study of shale dewatering. }\end{array}$ \\
\hline
\end{tabular}


Exhibit 2-11

DESIGN WELL TESTS - PROPOSED

\begin{tabular}{|c|c|c|}
\hline WELL & LaFourche Crossing & Gladys McCall \#2 \\
\hline LOCATION & $\begin{array}{l}\text { LaFourche Parish, LA } \\
\text { (South of Thibodaux) }\end{array}$ & $\begin{array}{l}\text { Cameron Parish, LA } \\
\text { ( } 45 \text { miles southeast of } \\
\text { Lake Charles) }\end{array}$ \\
\hline DEPTH & $17,200^{\prime}$ & $17,000^{\prime}-18,000^{\prime}$ \\
\hline FORMATION(S) & $\begin{array}{l}\text { Robulus L } 43 \text { Zone Plater Sand Series } \\
\text { (Mid-Miocene to Lower Miocene) }\end{array}$ & $\begin{array}{l}\text { Frio Formation } \\
\text { (Miocene, Oligocene Series) }\end{array}$ \\
\hline $\begin{array}{l}\text { NET THICKNESS } \\
\text { POROSITY } \\
\text { TEMPERATURE } \\
\text { PRESSURE } \\
\text { SALINITY } \\
\text { SATURATION } \\
\text { DRAINAGE VOLUME }\end{array}$ & $\begin{array}{l}740^{\prime}+ \\
19-30 \% \\
240-266^{\circ} \mathrm{F} \\
13,500 \mathrm{psi} \\
45,000 \mathrm{mg} / 1 \\
30-40 \mathrm{scf} / \mathrm{bbl} \\
21 / 4 \mathrm{mi}^{3}\end{array}$ & $\begin{array}{l}750^{\prime}-1,500 \\
15.0-23.5 \% \\
319^{\circ} \mathrm{F} \\
15,000 \mathrm{psi} \\
50,000-70,000 \mathrm{ppm} \\
\frac{-}{2.5-3: 2 \mathrm{mi}^{3}}\end{array}$ \\
\hline PRODUCTION RATE & $50,000 \mathrm{bbl} / \mathrm{d}$ & $40,000 \mathrm{bbl} / \mathrm{d}$ \\
\hline DISPOSAL AQUIFIERS & $4,565^{\prime}-4,860^{\prime}$ & $1,970^{\prime}-4,470^{\prime}$ \\
\hline $\begin{array}{l}\text { DURATION } \\
\text { CONTRACT } \\
\text { TESTING }\end{array}$ & $\begin{array}{l}26 \text { months } \\
10 \text { months }\end{array}$ & $\overline{24}$ months \\
\hline REMARKS & Four sand bodies available for testing. & $\begin{array}{l}\text { Three and probably four sand bodies } \\
\text { available for testing. }\end{array}$ \\
\hline
\end{tabular}


- Dow Sweezy \#1, Louisiana. This aquifer, located about twelve miles south of Lafayette, in Vermilion Parish, will be tested over approximately nine months by drilling a 13,600 foot well into a small geopressured water sand and depleting the aquifer. For the first time in the Design Well program a gravel pack completion will be used. This R\&D study is designed to supply, in a relatively short period of time, essential data on reservoir producibility, nature of produced fluids, gas yield over time, reinjection of high volumes of waste water, possible shale dewatering and environmental concerns, such as subsidence.

- Lafourche Crossing. A well has been proposed for a geopressure-geothermal reservoir near Lafourche Crossing, Louisiana. The project will include the engineering, drilling, and completion of a production scale geopressured well; a production and reservoir testing program; an environmental monitoring program; and a scientific program to increase the basic understanding of the geopressured zone.

- Gladys McCall \#2. This site was originally part of the "Wells-of-Oppurtunity Program." A design well is now planned after an unsuccessful reentry attempt in the Gladys McCall Well \#1. The net sand thickness of the geopressured interval, the anticipated areal extent of the reservoir, the predicted bottom hole pressure and temperature along with the low salinity has qualified this prospect area as one of the most attractive for resource investigation.

The Lafourche Crossing well and Gladys McCall \#2 will be included in the Design Wells management contract signed in the fall of 1980. The four Design Wells planned under that contract include two shallow wells (about 12,000 feet) to be tested for six months each and two deep wells (about 17,000 feet) to be tested for two years each. In addition to the Lafourche Crossing prospect, three other of the most favorable prospects from Texas and Louisiana will be selected, based on the best available geological, geophysical, and environmental information. The Design Well program is expected to continue through FY86 at which time 12 Designs Wells will have been drilled and tested.

c) Site Selection

Sites for Wells of Opportunity are selected from recommendations made by a Well Selection Committee. Initially a contractor monitors wells being drilled along the U.S. Gulf Coast and makes recommendations on wells that meet the criteria of the Program. When the well appears favorable, data is developed, for example, the depth of the well, the location, and the 'geology. The Well Selection Committee, consisting of representatives from the USGS, DOE, University of Texas, and Louisiana Geological Survey, then review the recommended wells. If the well fits the purpose of the program, the group can recommend to the DOE that the well be tested. The same group also reviews data collected during the tests and recommends to the DOE whether to continue the test or to extend the test.

The prospect locations for Design Wells are determined by a Site Selection Committee consisting of representatives from the USGS, DOE, University of Texas, Louisiana State Universtiy, and the State Geological Survey of Louisiana. This committee meets and prioritizes available prospects and makes recommendations. DOE then selects the prospects and the detailed sites.

\subsubsection{Activity 2. Demonstration of Recovery Potential}

\subsubsection{Purpose}

The purpose of the second technical activity is to establish whether the energy of geopressure-geothermal resources can be technically and economically recovered. This demonstration is essential for industry interest and development. It requires establishing the technical feasibility of high volume brine production and disposal and the economic recovery of the produced energy; gaining an improved technical and mathematical understanding of the resources; and resolving any legal and institutional constraints that may impede timely development. This activity will be conducted concurrently with the Resource Definition activity and will continue throughout the program. 


\subsubsection{Approach}

The approach to this activity consists of the following three components that are shown diagramatically on Exhibit 2-12.

- Recovery Technology. Develop new or adapt existing technology to demonstrate the technical feasibility of producing geopressured aquifers economically.

- Supporting Research. Develop an improved understanding of geopressured reservoir and fluid characteristics through laboratory work and reservoir models.

- Constraint Resolution. Identify legal and institutional constraints and work with local and state sources to resolve them.

Recovery Technology R\&D is being addressed in connection with the well drilling and testing programs. Supporting research and resolution of Development Constraints are being conducted by universities and other organizations.

In addition to the work being done under the Geopressure-Geothermal Program, the experience and technology from the Hydrothermal Program will be applied to the geothermal component of the resource.

\subsubsection{Discussion of Activity Components}

\section{Recovery Technology}

The recovery technology component consists of three main areas; (a) production technology, including downhole and surface equipment; (b) instrumentation; and, (c) disposal systems.

a) Production Technology

While the equipment needed for geopressured well testing is typically that normally available from oil field vendors, these tools, techniques, ad processes need to be adapted to operating conditions far more severe than those normally encountered. Of highest priority is the development of process equipment and operating techniques to handle saline fluids with temperatures greater than $250^{\circ} \mathrm{F}$ and pressures greater than $5,000 \mathrm{psi}$.

i) downhole equipment

Six priority areas in downhole equipment need to be addressed by the Geopressure-Geothermal Program:

1. Develop improved drilling technology to reduce the incidence and severity of well problems.

2. Develop the technology and techniques to enable the successful casing of geopressure-geothermal wells.

3. Improve cementing techniques to ensure production of the brines for the designed life of the well.

4. Develop technology to enable production of the brines for the designed life of the well.

5. Develop methods to optimize the long-term reinjection of the produced brines in disposal wells.

6. Ensure the availability of techniques and materials to economically "workover" geopressure-geothermal wells.

ii) Surface Equipment

Integrated surface equipment is required to efficiently and reliably capture the chemical, thermal, and mechanical energy. The current strategy for methane extraction is to adapt existing technology while also investigating the feasibility of developing alternate means for methane extraction.

Technology for recovering the thermal energy is being developed under the Hydrothermal Program and will be readily adaptable to Geopressure-Geothermal Program needs. This technology involves the development of binary fluid systems with secondary 


\section{Exhibit 2-12}

\section{RECOVERY POTENTIAL ACTIVITY}

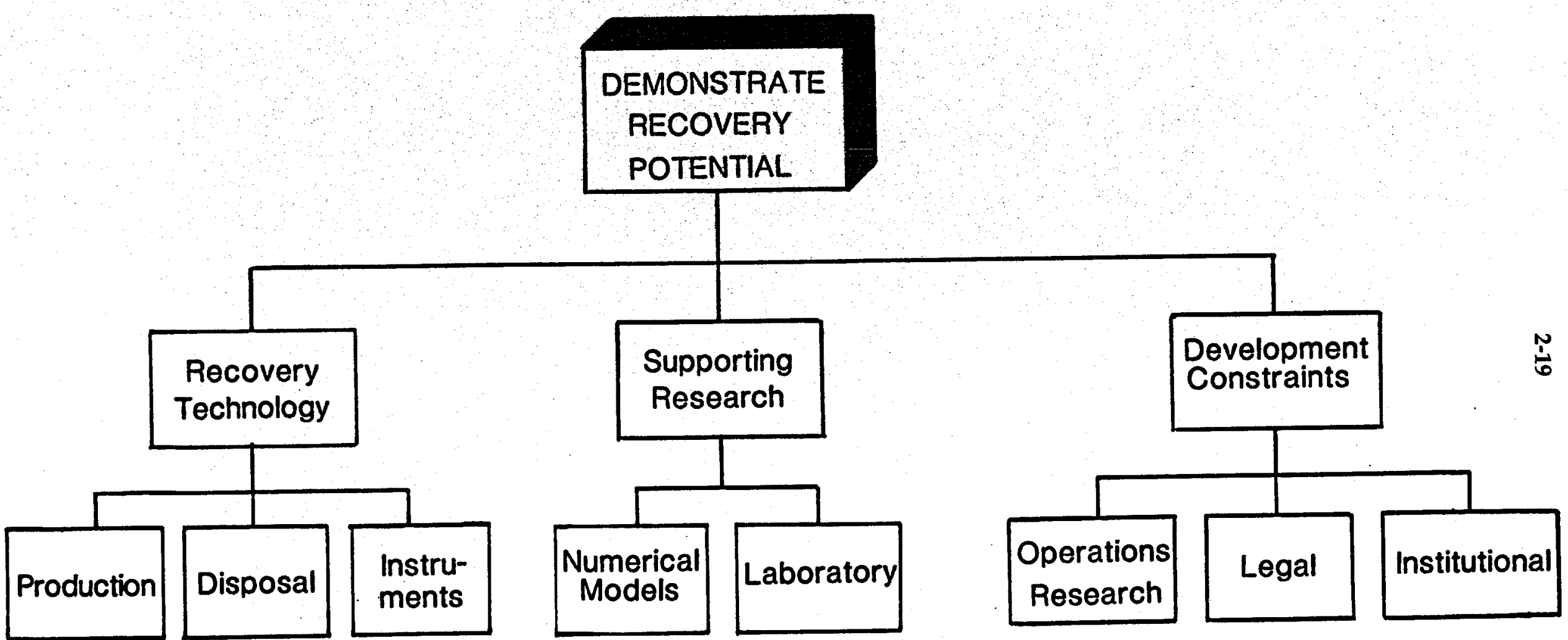

Purpose : Develop Technology for Economic Production

Implementation :
Develop Technology in Connection With Well Testing
Develop Understanding of the Resource

Study Key Reservoir Parameters and Develop Reservoir Models
Resolve Non-Technical Constraints to Identify and Resolve Constraints 
working fluids that can convert moderate temperature geothermal energy to electric power.

For optimum recovery of mechanical energy, existing technology must be adapted to the corrosive and briny environment and higher inlet pressures.

Finally, initial feasibility and engineering studies are required on how to integrate the three sources of energy into a total energy system and on the use of dispersed energy production facilities.

\section{b) Instrumentation}

The geopressured resource, with its high temperatures and pressures, severely taxes the existing field measurement tools. Tools that perform well at pressures of up 5,000 psia and temperatures up to $250^{\circ} \mathrm{F}$, fail in the geopressured zone due to electronic circuit problems and mechanical straining of critical components. Ultra-high pressure equipment (in excess of 10,000 psia) is generally neither available nor reliable at high temperatures.

To obtain accurate reservoir engineering data, instruments must be developed that can measure in situ conditions of pressure, temperature, and fluid composition. To meet these instrumentation needs, Sandia Laboratories is working with industry on the development of a reliable high temperature pressure gauge. Downhole samplers are being developed at Lawrence Berkeley Laboratory and at IGT through funding by GRI. These instruments are essential for measuring the critical formation properties and reservoir extent. In addition, measurements of flow conditions in the tubing and fluid sampling on the bottom will provide key data for hydrodynamic calculations and scale control.

c) Disposal Systems

Since surface disposal of the produced brines will normally be precluded, disposal will be by reinjection in most cases, although offshore disposal may be feasible in some instances. A major concern is to determine whether the waters injected into disposal aquifers are chemically compatible with the reservoir waters. These concerns will be addressed through the well testing programs.

The following considerations apply to fluid disposal:

- Surface Disposal. Surface disposal of the potentially large volumes of brine may have adverse biological and ecological implications. In addition, existing regulatory constraints may preclude this option in most cases.

- Shallow Disposal. The large volumes of water to be injected may require multiple reinjection wells to prevent formation fracturing. Experience will be gained on shallow injection during the well testing programs to better understand these phenomena.

- Deep Injection. Disposal into the producing aquifer would require the drilling of deep injection wells and would be a more costly alternative, both in capital and operating costs. Disposal by this method is generally not possible during the early years of production from a reservoir, due to the potential over-pressurization of the reservoir leading to fracturing. Therefore, even with deep reinjection, other means of disposal will have to be used during the initial phase of reservoir development, although deep reinjection may be necessary for reservoir pressure maintenance.

- Offshore Disposal. This may require construction of pipelines out into the Gulf for onshore wells. Before such a scheme can be seriously considered, even for offshore wells, major environmental and regulatory constraints need to be resolved.

\section{Supporting Research}

Supporting research is essential when problems common to resource development in general cannot be solved as part of the well tests. 


\section{a) Laboratory Studies}

Five perceived problems that are being addressed by laboratory research are discussed below:

- Methane Solubility. The purpose of a project at Idaho State University is to determine the solubility of methane in water under varying conditions of salinity, temperature, pressure, carbon dioxide, and hydrocarbon content. Attention is also being directed to methane solubility at low pressures.

- Methane Stripping. The reinjection of brines after methane recovery may require a significant amount of energy. Lawrence Livermore Laboratory is currently investigating three methane extraction methods to improve recovery efficiency of the dissolved methane and to reduce the economics and pumping costs of extraction:

-Desorption or gas stripping with the use of either halogenated hydrocarbons or nitrogen.

-Solvent extraction with the use of very low soluble organics, such as paraffinic hydrocarbons at high temperatures and pressures.

-Mechanical devices that are variations of positivedisplacement hydraulic engines and hydraulic turbines with separators.

- Scaling and Corrosion. The scaling and corrosion of integral parts of the production system from contact with the hot, saline brines can lead to an early system failure with resulting high production costs. Site-specific studies are made by DOE, while inhibitor studies are being conducted at Rice University with funding by GRI.

- Relative Permeability. The purpose of a study at the University of Southern California is to ascertain the phenomena of "free gas evolution" - whether methane can be produced from geopressured aquifers at gas-water ratios which exceed the theoretical gaswater ratios in undisturbed aquifers. Simulated geopressured aquifers will be constructed to represent consolidated and unconsolidated reservoirs. In situ conditions will be created and the "aquifers" will be produced under different techniques.

- Rock Mechanics. The objective of a project at the University of Texas at Austin is to collect data, using cores from Design Wells, on triaxial compression, relative permeabilities, and acoustic velocities. The laboratory is capable of restoring cores to near in situ conditions to analyze the compaction of sediments in geopressured aquifers as a drive mechanism, and other reservoir physical properties that affect production and the potential for subsidence. The data from this research is used in computer simulation to help determine reservoir physical properties and drive mechanisms that affect production and subsidence.

b) Numerical Models

Improved numerical models have been developed to simulate the production from geopressured reservoirs for the University of Texas by Systems, Science and Software. The Institute of Gas Technology and Intercomp are currently using a simulation program to determine the sensitivity of production economics to relative permeability, cost of water disposal, reduction of permeability from production, changes in reservoir drive, and the effects of two-phase flow.

\section{Analysis of Development Constraints}

The purpose of constraint analysis is to identify and resolve any constraints that may impede development of the geopressure-geothermal resources and includes work on legal, institutional, and operations research (total systems) issues.

a) Legal Issues

The General Land Office of Texas has addressed the legal issues that affect the development of the geopressure-geothermal resources in the State of Texas, with the following findings: 
- The Texas Geothermal Act establishes that all components of the geopressure-geothermal resources are to be treated as mineral resources. The intent of the legislature was that the geothermal heat and pressure not be wasted when producing the methane from geopressured formations.

- Under current federal tax statutes, wells producing from geopressured aquifers are not treated as gas wells. Geothermal resources are not specifically mentioned in Texas tax statutes. The natural gas occupation tax would probably apply to the methane produced from geopressured brine. In January 1980 federal price controls were eliminated for high-cost natural gas, including gas produced from geopressured brines.

- The major environmental regulations applicable to geopressure-geothermal resources are those water quality regulations that control brine disposal. Currently, both state and federal regulations apply to the surface discharge and reinjection of brine.

- An ownership question exists in part because of a lack of clear legal definition concerning the nature of the resources. If the geopressure-geothermal resources are considered to be "water," ownership rights and control normally lie with the surface owner; if the resources are a "mineral," ownership rights and control belong to the owner of the subsurface or mineral estate.

- Neither the legislature nor the courts of Texas have directly addressed the question of whether a geothermal resource belongs to the surface estate or to the mineral estate. The potential for court action remains, however, as case law is unclear on this point.

- The questions of correlative rights and subsidence liability are still undecided.

A similar assessment of laws and regulations has been completed for the State of Louisiana by the Law Center of Louisiana State University. The purpose of the report was to discuss the legal framework within which the geopressure-geothermal resources will have to be developed in Louisiana. It identified legal problems which may be created by the development of the geopressure-geothermal resources and, where possible, offered solutions to those problems or at least techniques which might be considered in their resolution. It also assembled a compendium of those statutory or regulatory provisions which may regulate or affect resource development.

b) Institutional Issues

Institutional issues include the planning for technological changes or innovations, such as the development of geopressure-geothermal resources and consideration of impacts on and consequences for local communities. These issues may be site-specific. Comparisons and contrasts of the areas in terms of some variables relevant to resource development will therefore help to provide regional assessments of institutional barriers to resource development.

c) Operations Research

Two operations research projects have been funded - one at the University of Texas and the other at Louisiana State University.

- The University of Texas report presents details of development scenarios for the geopressure-geothermal resources in Texas under various development rates and configurations (shallow or deep reinjection).

- The Louisiana State University report is based on the development of the geopressure-geothermal resources in four parishes (Vermilion, Cameron, Calcasieu, and Acadia) where resource data is available.

In addition, local studies will be carried out on local use of the thermal energy in areas recommended for well testing. One such project is already underway in connection with the Design Well site in Brazoria County. Also, a study on the feasibility of geopressure-geothermal energy production southeast of the Abbyville Field, Vermilion Parish, Louisiana has been conducted by the University of Southwestern Louisiana. 


\subsection{GENERAL PROGRAM SUPPORT}

As part of General Program Support, considerable effort will be directed to the collection, interpretation, and dissemination of test data to make information readily available to researchers, and the formulation of incentives to encourage industry to more aggressively pursue development of the geopressure-geothermal resources.

- Dissemination of Information. A Geopressure-Geothermal Information System is being created at the University of Texas to provide a centralized system for preparation and distribution of resource information. It will include:

-A library of digitized well logs from known geopressured areas, processed, and interpreted for the petrophysical and fluid properties of the reservoirs.

-Preparation and distribution of bibliographic information.

-Preparation and distribution of information on geopressure-geothermal resources to users at cost.

-Quarterly newsletter preparation and distribution.

-Development of computer software for log analysis, file management, plotting, and automated data entry.

- Information Exchange. DGE will continue to sponsor professional conferences which bring together representatives from industry, academia, and government. Such conferences are the GeopressureGeothermal Conferences held alternately in Louisiana and Texas and the informal Industry Forum meetings. These latter meetings, hosted by C.K. Geoenergy, are designed to bring together people doing research on geopressured aquifers and industrial participants who are interested in development of this resource. Meetings are held in the following areas:

-site selection

-drilling and testing

-environmental/lab research/legal

-technology overview

Meetings are held fairly regularly (one to three month intervals), at which results of ongoing research are presented, usually by the principal investigators so that information can be exchanged on a first-hand basis. Active participation is continually sought from industry, government entities, and the public. These meetings have also been supported by other agencies, such as EPA.

- Incentives Study. The University of Texas has completed a study on the potential impacts of various federal incentive programs on the commercial development of the Texas Gulf Coast geopressure-geothermal resources. The study contained the following conclusions:

- Government programs which reduce the uncertainties associated with resource development will be more effective in the near term than incentives that improve the economic return.

- The energy tax credits and the depletion allowance for methane from geopressured aquifers should be extended and additional incentives should be specifically directed to the geopressure-geothermal resources, if they are to be developed commercially during the 1980 's.

- A given incentive will not affect all potential participants in resource development equally. Differences in corporate and financial structure, regulation, and methods of resource utilization will cause the degree of encouragement given by a particular incentive to differ among industry types.

-At least through the mid-term the institutional structure for commercialization of the geopressure-geothermal resources will be based on utilization of its methane component. This structure will likely be comprised of some mix of the following four development profiles:

--production of methane by a petrochemical firm for use as feedstock of boiler fuel, 
--production of methane by a gas pipeline company for sale, -production of methane by an integrated oil and gas producer for sale and/or internal use, -production of methane by an electric utility for use as boiler fuel.

The purpose of developing a particular reservoir site will depend upon local conditions, so that all four profiles may exist simultaneously at different sites.

- There is little probability of substantial direct use of the thermal energy from geopressure-geothermal resources for process heating or chilling in the near future. Although there is considerable interest on the Gulf Coast in new, low-cost energy sources, the relatively low temperature of geopressure-geothermal fluids, the difficulty of long-distance transportation, the existence of unused low-grade "waste" heat, and the large capital costs associated with the heat exchangers required to use the fluids discourage the near-term process utilization of the gas thermal energy.

\subsection{FUTURE NEEDS AND PRIORITIES}

The activities in this Multi-Year Program Plan constitute the basic core program through FY86. Under this program, much of the fundamental definition of the resource, development of extraction technology, and initial environmental assessment would be completed and industry interest in the resource furthered. However, several important tasks will remain for subsequent years. These include:

Development of Total Energy Systems. Total energy systems are conceptually attractive because all the produced energy (chemical, thermal, and mechanical) is made available for use, thereby improving the economics. A further advantage of total energy systems is that gas need not be burned or power purchased for reinjection of produced brines. Conceptual analyses of total energy conversion systems will be conducted to identify the potential of these systems and the areas where technical advances are required. The program strategy foresees development and testing of advanced heat exchanger technology under the Hydrothermal Program, and the development of advanced methane extraction and kinetic conversion technology under the Geopressure-Geothermal Program. The building of such facilities for the Geopressure-Geothermal Program will occur after FY86.

Testing of Advanced Recovery Methods. Under conventional recovery practices, the ultimate recovery of the in-place brine is expected to be a few percent. Two approaches that have been suggested for significantly increasing this recovery, are: (1) maintaining the pressure in the producing aquifer by deep reinjection, this could possibly allow 50 percent of the in-place energy to be recovered; and (2) developing a way to evolve free gas from solution in the aquifer using artificial lift and thus building a critical gas saturation to produce more of the in-place resource. Further analysis is required to establish the economic viability of these two schemes.

Sponsoring Localized Use of the Produced Energy. A market survey of 267 low-grade process heat users was conducted along the Texas Gulf Coast to define the future market. Although potential markets for the heat were identified, a main conclusion was that industry considered the geopressure-geothermal resources to be in the initial stages of development and that considerable $R \& D$ will be required before commercialization.

Because the thermal and mechanical energy would have their greatest economic value when used directly and locally, it is important to fully examine this market potential and the development constraints. It is particularly important to determine if the local power companies and utilities near these resources could become co-sponsors for developing and using the geopressure-geothermal resources. 


\section{CHAPTER 3.0 ENVIRONMENTALSTUDIES}

\subsection{INTRODUCTION}

Development of geopressure-geothermal resources involves well drilling, fluid extraction, methane separation, thermal hydraulic energy conversion, and fluid disposal. Each of these activities can have an impact on the environment. While in many respects these environmental effects will be similar to those encountered in the development of oil, gas, and hydrothermal resources, the higher pressures of the produced fluids, up to 16,000 psi, and the tremendous rates of fluid withdrawal, up to 40,000 barrels or more per well per day, present the potential for more serious environmental problems. The two areas of most concern are subsidence and fluid disposal.

\subsubsection{Subsidence}

Subsidence is considered the most important environmental issue related to geopressure-geothermal resource development, since failure to resolve or mitigate this problem would seriously impede development.

The Texas and Louisiana Coastal Zones are areas of multiple land use. The areas contain intensive agricultural, industrial and fishing industries and major urban population centers. As a coastal plain, elevations in many localities are not significantly above sea level; therefore large scale subsidence could have a serious impact.

Concern for potential subsidence implicitly includes concern for induced seismicity due to their common basic cause-rapid and large volume fluid withdrawal. However, the Gulf Coast is aseismic, and is an area of generally low seismicity. Microseismic monitoring over the past several years by the Bureau of Economic Geology in Texas, some of it connected with large disposals, have not shown any surface effects resulting from seismic events.

\subsubsection{Fluid Disposal}

To minimize the adverse impact of geopressure-geothermal energy development on ground and surface water, wildlife and vegetation, environmentally acceptable methods for the disposal of large volumes of spent brines must be identified and evaluated. The produced brines are saline and may contain trace elements above acceptable levels. A possibility in some areas may be offshore disposal, but in most cases injection of the waste water into subsurface formations will be the only acceptable option.

\subsubsection{Other Concerns}

In addition to the concerns discussed above, accidental spills or occasional surface discharge of brine can harm the soil, vegetation, and wildlife in the vicinity of the sites. Large spills or long-term leakage of the brine can contaminate surface streams and shallow aquifers from which drinking water is extracted. Techniques and practices to control and mitigate such effects, however, are currently available and are being implemented.

While air quality could be impaired by the release of hydrogen sulfide $\left(\mathrm{H}_{2} \mathrm{~S}\right)$, ammonia $\left(\mathrm{NH}_{3}\right)$ or non-methane hydrocarbons, it is anticipated that this problem can be readily prevented or controlled.

The land usage and noise problems associated with geopressure-geothermal resource development are expected to be similar to those encountered with oil and gas development and thus require no special procedures or controls.

\subsection{PURPOSE}

The purpose of the Environmental Studies activity is to anticipate and understand the environmental consequences of geopressure-geothermal resource development and to mitigate any adverse impacts. 


\subsection{APPROACH}

The approach of the Environmental Studies activity is to adapt existing technologies from other programs and industries as much as possible in connection with the well testing to meet the following program objectives:

1. Identify, evaluate, and monitor the identified range of potential environmental consequences.

2. Develop and/or demonstrate cost-effective controls and management methods to meet existing and anticipated regulatory pollution control standards.

3. Develop detection, prevention, and mitigation techniques for environmentally damaging events not subject to direct regulatory control, such as subsidence.

4. Adapt environmental control technology and procedures which have been developed for oil, gas, and hydrothermal resource development.

5. Conduct environmental assessments and monitoring of well sites to develop a better understanding of environmental concerns and controls.

The approach adopted by DOE consists of prospect-specific as well as generic activities. The components of the Environmental Studies activity are shown on Exhibit 3-1.

The prospect-specific activities focus on individual development sites and include regional baseline studies, environmental data collection and analyses and monitoring of the environmental impact of site development.

The environmental parameters addressed by the generic activities will be monitored at all sites at which geopressure-geothermal development is undertaken and include studies of subsidence, release of toxic gasses and disposal of the spent brine.

\subsection{DISCUSSION OF ACTIVITY COMPONENTS}

\subsubsection{Prospect-Specific Activities}

Because each well site is unique, a significant part of the Environmental Studies activity must be prospect-specific. The prospect-specific activities examine in detail the concerns initially raised by the generic studies. In the context of a typical geopressure site, the sequence and relationship of environmental control activities associated with its development are displayed on Exhibit 3-2, and discussed below:

a) Baseline Assessment and Environmental Reports. This element involves the collection of baseline environmental data for monitoring changes which occur during the development phase and for providing input to environmental compliance documentation required under NEPA. It is expected that specific environmental reports will only be prepared for Design Well sites, and a general assessment for the area and geologic formations will be used for the Wells of Opportunity. In preparation, two steps have been completed:

- The Bureau of Economic Geology (BEG) at the University of Texas has studied the geopressured fairway areas in Brazoria and Kenedy counties to identify any active geologic processes, assess current land use, and collect air and water quality baseline data. This study is being used in preparing environmental assessment reports for well test activity in these two counties.

- Similar work has been completed by BEG for the areas overlying geopressured aquifers of the Wilcox and Frio formations in Texas.

b) Environmental Monitoring. Environmental monitoring is carried out in conjunction with the development activities. Prior to development, a monitoring program is formulated and implemented before the first activity at the site (i.e., moving the well drilling equipment) occurs.

\section{- Louisiana Gulf Coast Study}

-The Institute for Environmental Studies at Louisiana State University has developed a plan for the long-term environmental assessment of geopressure-geothermal resource development in the region. The plan identified the major environmental concerns and evaluated their potential impact assuming a full-scale development scenario. 


\section{Exhibit 3-1}

\section{ENVIRONMENTAL STUDIES ACTIVITY}

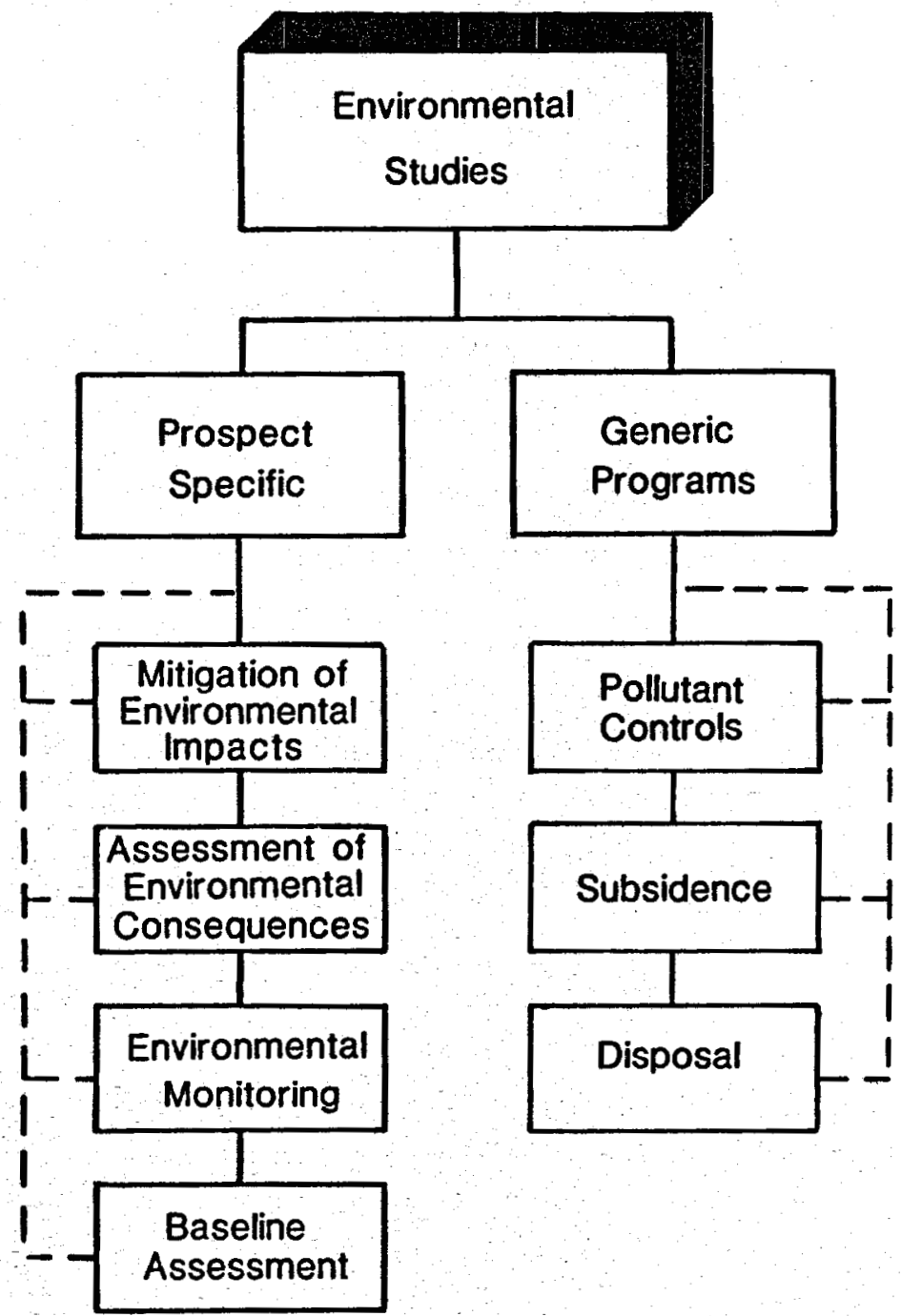

Purpose : Identify, evaluate and control unique environmental problems at each prospect
Develop generic techniques and solutions to address major environmental problems

Implementation :

- Baseline Data Collection

- Monitor Effects of Ongoing Activities

- Impact Assessments

- Develop and Utilize Control Technology
- Modeling Studies

- Generic Assessments

- Control Technology Development

- Ecosystem Response Studies

- Data Analysis Techniques

- Instrument Development 


\section{Exhibit 3-2}

\section{ELEMENTS OF THE ENVIRONMENTAL CONTROL PLAN}

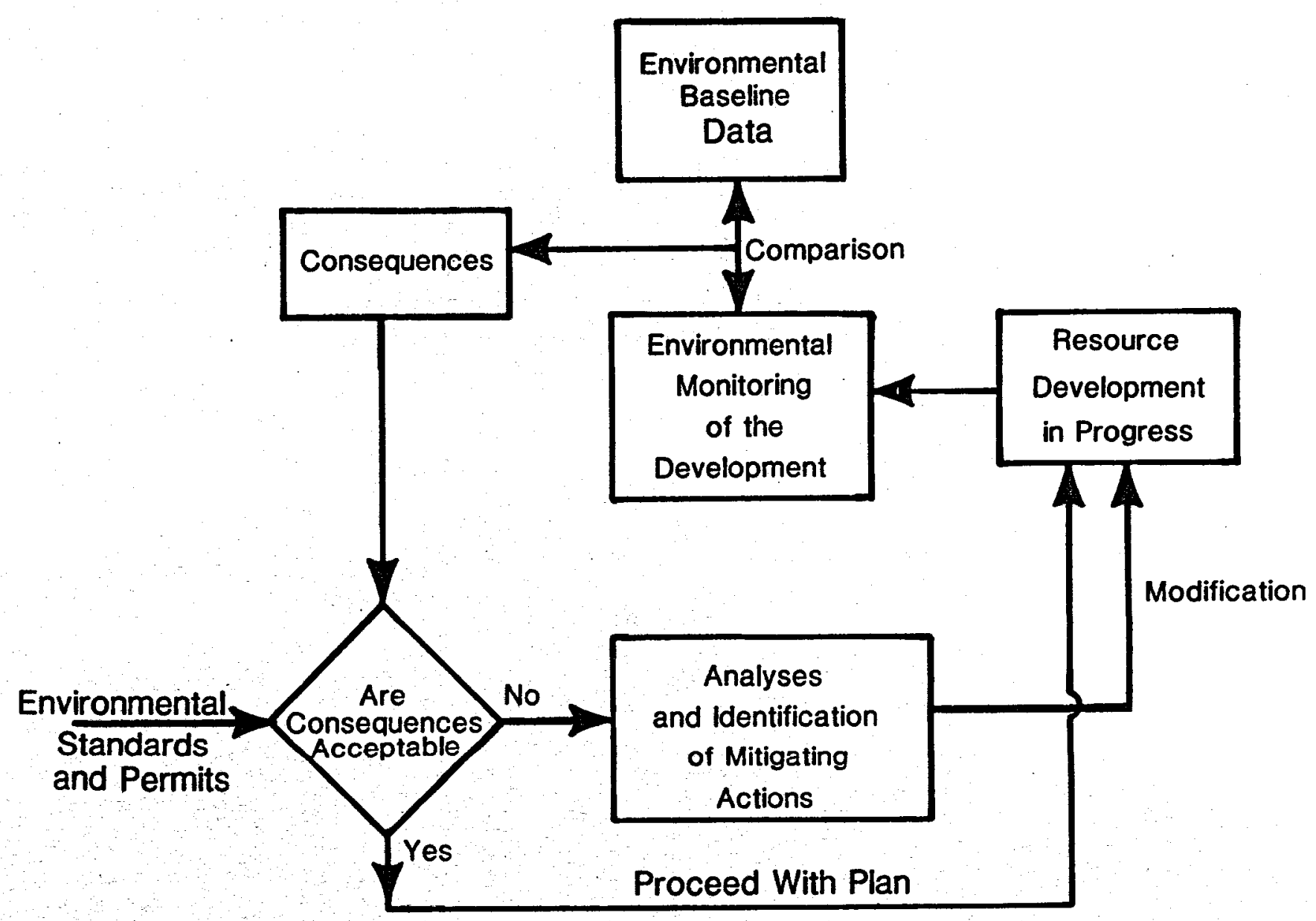


-Another study at Louisiana State University compared six high-priority prospect areas to determine how development of each prospect might affect land use, geology, air quality, water resources, ecological systems, and natural hazards. The information from this study has been used as background data for site-specific environmental reports.

- Louisiana State University is also arranging for monitoring at a number of specific sites including Sweet Lake, Lafourche Crossing and the Dow Parcperdue area.

- Texas Gulf Coast Study

Environmental monitoring studies are being conducted at the Design Well site in Brazoria County, Texas. The objectives of this program are to provide baseline data and to conduct a set of environmental surveys prior to, during, and after large production tests. The work includes:

-air quality monitoring,

-water quality monitoring,

-microseismic surveys,

-base leveling surveys,

-disposal well monitoring, and

-noise impact surveys.

The approximate data collection frequency is: daily for air quality monitoring, monthly for water quality surveys, and continuous for ground stability and microseismicity studies. Base leveling and monitoring is conducted both before and during the production tests.

c) Assessment of Environmental Consequences. The data collected during baseline assessment and environmental monitoring will be analyzed to determine the broader impacts of resource development on the environment of a site.

The Oak Ridge National Laboratory is responsible for the preparation of site-specific environmental impact statements, environmental assessments, and other NEPA compliance documentation in support of the geopressure well test programs. To date:

- Environmental assessments have been completed for the Wells of Oportunity Program for the appropriate Gulf Coast formations.

- Site-specific assessments have been completed or are being completed for sites in Louisiana.

d) Mitigation of Environmental Impacts. If the environmental impacts associated with the development of the resource are unacceptable, actions will need to be taken to mitigate the adverse impacts and to render the environmental consequences acceptable if the activity is to proceed; in extreme cases the development may be abandoned.

The environmental monitoring, assessment, and control program for the Brazoria site is a good example of site-specific activities. At this site, the environmental assessment activities addressed the following dimensions of the environmental concerns:

- Land subsidence and induced seismicity

- Ground water quality and hydrologic alterations

- Ecosystems quality

- Air quality and noise

- Protection of archeological and cultural resources

\subsubsection{Generic Environmental Activities}

Part of the environmental studies and control technology is generic in nature and not dependent on the characteristics of any particular site. For example, subsidence modelling, instrumentation and pollutant control technology, development, and ecosystem response studies can be developed to be applicable to numerous potential sites, and experience from the Hydrothermal Program can be adapted. Thus, the generic environmental activities are designed to provide support to the site-specific activities and to minimize any duplication of efforts. 
The Oak Ridge National Laboratory is responsible for the preparation of generic environmental assessments which address the following concerns for the entire well-test program:

- Induced subsidence and seismicity

- Liquid discharges and disposal

- Air emissions

- Disposal of solid wastes and trace elements

Since subsidence is the major environmental concern in geopressure-geothermal development, the subsidence program is utilizing the knowledge and expertise developed under the Hydrothermal Program. Lawrence Berkeley Laboratory, the lead organization for hydrothermalrelated subsidence studies, provides major support in this area. 


\section{CHAPTER 4.0 MANAGEMENT PLAN}

The Geopressure Resources Section of the Division of Geothermal Energy has overall management responsibility for the Geopressure-Geothermal Program, as shown on Exhibit 4-1.

Management of the drilling, completing, and testing of reservoirs is administered by the Nevada Operations Office and its Houston Geopressure Projects Office. Contractors are used for the actual drilling and testing of wells. Eaton Operating Company, Inc. is the Wells of Opportunity contractor and Fenix and Scisson, Magma Gulf Technadril, and Dow Chemical Company are contractors for the Design Wells planned to date. Technadril/Fenix and Scisson, a joint venture, currently has a contract to drill and test four additional Design Wells.

The Geopressure Projects Office in Houston manages the supporting research and technology development, and directs efforts using national laboratories, universities, and industry research institutes as research contractors.

A Technical Review Board serves in an advisory capacity for reviewing Design Well proposals and selecting candidates for Wells of Opportunity testing. This review board is composed of members from the University of Texas, Louisiana State University, the U.S. Geological Survey, and the DOE Nevada Operations Office/Geopressure Projects Office Houston. 


\section{Exhibit 4-1}

\section{MANAGEMENT ORGANIZATION OF THE DIVISION OF GEOTHERMAL ENERGY}

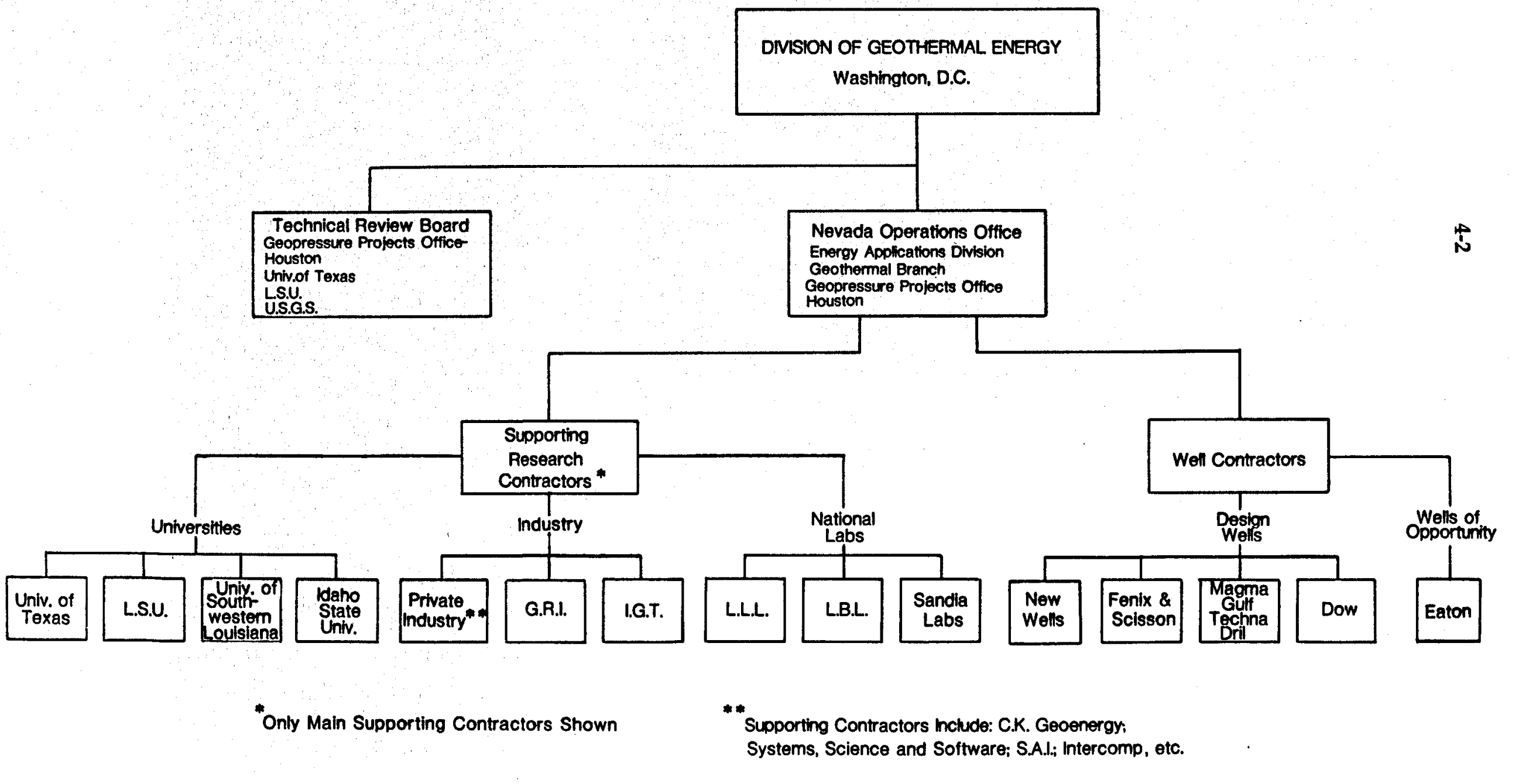




\section{CHAPTER 5.0 FUNDINGREQUIREMENTS}

The funding required for the FY81 through FY86 Program Plan is shown on Exhibit 5-1. The budget peaks in FY84, reflecting the heavy concentration of well drilling, completion, and testing in the beginning of the eighties.

The distribution of funds is shown by activity on Exhibit 5-2, and reflects the R\&D nature of the Program. The major part of the funding is devoted to the Resource Definition activities necessary to select, design, and drill wells from which basic resource data will be obtained. The funds in the Recovery Potential activity are used to improve the mathematical modelling of geopressured aquifers, to develop the essential downhole measurement and instrumentation technology, and to build the surface facilities required to efficiently separate the methane from the high-pressure, hot, saline brines. In addition, funds are provided under this activity to identify potential users and producers and to plan for the development of the resource. The Environmental Studies activity funds the local monitoring at well sites and generic environmental studies of the geopressure-geothermal resources.

Exhibit 5-3 shows the funding from FY81 through FY86 by activity as a function of the developmental stages that the Geopressure-Geothermal Program will encounter during these six years. Resource Definition remains heavily in the Technology Development stage, although Engineering Development begins to be undertaken in the latter years. The Recovery Potential activity moves from the Technology Development stage to the precommercialization Engineering Development stage during the plan period. Environmental $R \& D$ is directed toward the demonstration and eventual commercial application of the technology. 


\section{Exhibit 5-1}

\section{GEOPRESSURE PROGRAM FUNDING PROJECTIONS}

Funding Required for R\&D Program Plan

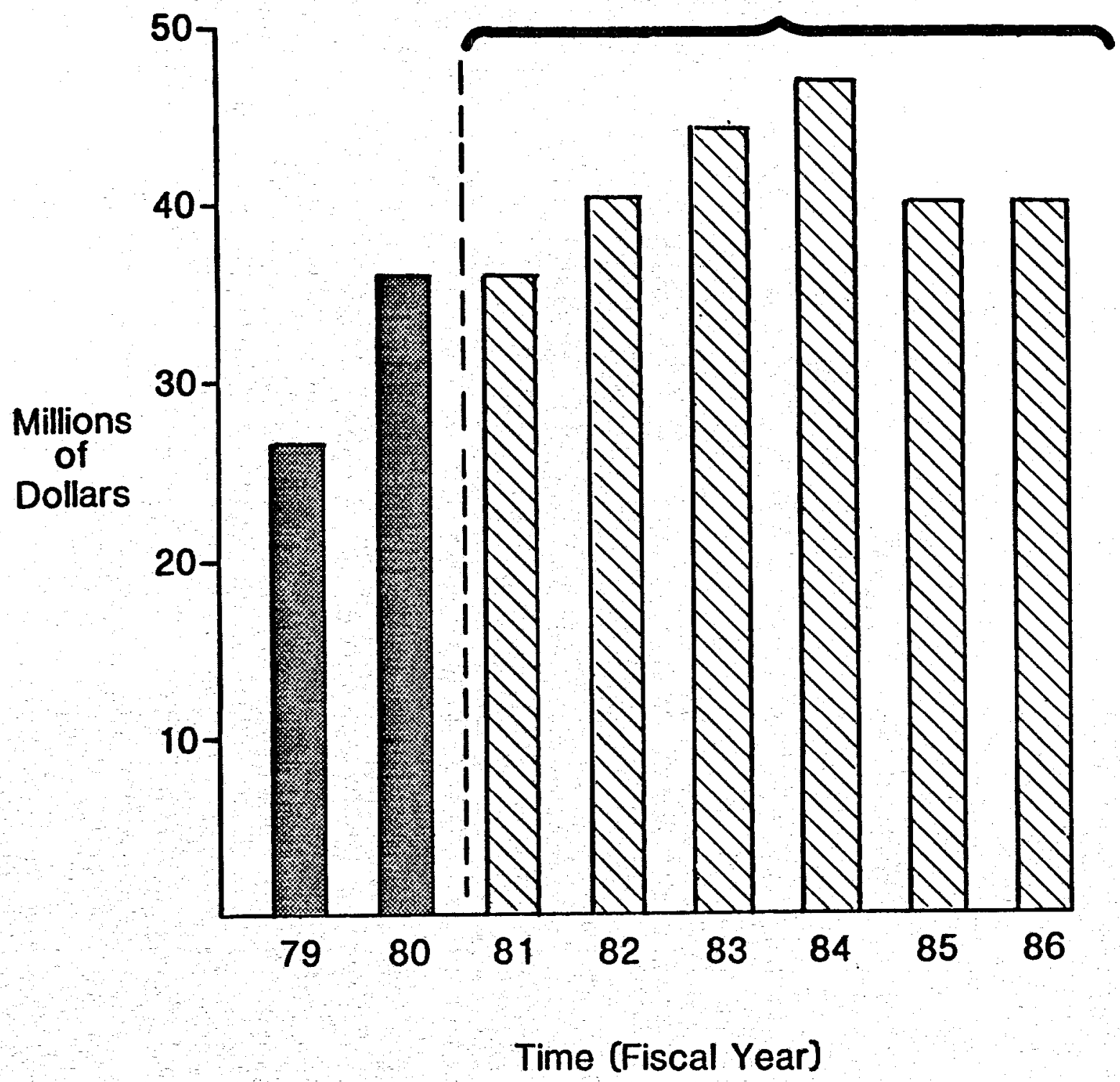

Total FY 81-86 : $\$ 247.5$ million 1980 Onward in Constant Dollars 
Exhibit 5-2

MULTI-YEAR FUNDING REQUIREMENTS

(Thousands of FY80 Dollars)

\begin{tabular}{|c|c|c|c|c|c|c|c|c|}
\hline & FY $79^{1}$ & FY 80 & FY 81 & FY 82 & FY 83 & FY 84 & FY 85 & FY 86 \\
\hline Resource Definition & 24,800 & 33,305 & 31,200 & 35,287 & 38,610 & 41,260 & 33,800 & \\
\hline $\begin{array}{l}\text { Determination of } \\
\text { Recovery Potential } \\
\text { Environmental Studies }\end{array}$ & $\begin{array}{r}700 \\
1,200\end{array}$ & $\begin{array}{r}2,014 \\
681\end{array}$ & $\begin{array}{l}2,600 \\
2,200\end{array}$ & $\begin{array}{l}2,900 \\
2,200 \\
\end{array}$ & $\begin{array}{r}3,300 \\
2,300 \\
\end{array}$ & $\begin{array}{l}3,300 \\
2,400\end{array}$ & $\begin{array}{l}3,800 \\
2,400 \\
\end{array}$ & \\
\hline $\begin{array}{l}\text { Total Budget Authority (BA) } \\
\text { Total Budget Outlays (BO) }\end{array}$ & $\begin{array}{l}26,700 \\
16,983\end{array}$ & $\begin{array}{l}36,000 \\
27,286\end{array}$ & $\begin{array}{l}36,000 \\
34,110\end{array}$ & $\begin{array}{l}40,387 \\
44,000\end{array}$ & $\begin{array}{l}44,210 \\
46,000\end{array}$ & $\begin{array}{l}46,960 \\
46,000\end{array}$ & $\begin{array}{l}40,000 \\
44,000\end{array}$ & \\
\hline
\end{tabular}

${ }^{1}$ FY79 Dollars

Exhibit 5-3

FUNDING REQUIREMENTS BY MAJOR R\&D PHASES*

Initial Research Technology R\&D Commercialization

\begin{tabular}{|c|c|c|c|c|c|c|c|}
\hline & $\begin{array}{l}\text { Basic \& } \\
\text { Applied } \\
\text { Research }\end{array}$ & $\begin{array}{l}\text { Exploratory } \\
\text { Development }\end{array}$ & $\begin{array}{l}\text { Technology } \\
\text { Development }\end{array}$ & $\begin{array}{l}\text { Engineering } \\
\text { Development }\end{array}$ & Demonstration & $\begin{array}{l}\text { Production } \\
\text { Operations } \\
\end{array}$ & $\begin{array}{r}\text { Total } \\
\text { FY81-86 } \\
\end{array}$ \\
\hline $\begin{array}{l}\text { RESOURC } \\
\text { Geologic St } \\
\text { Wells of O } \\
\text { Design We }\end{array}$ & $\begin{array}{l}\text { DEFINITIC } \\
\text { lies } \\
\text { ortunity }\end{array}$ & & $\begin{array}{r}5.0 \\
72.0 \\
116.0\end{array}$ & 5.4 & & & \\
\hline $\begin{array}{l}\text { DEMONS } \\
\text { Technolog } \\
\text { Supporting } \\
\text { Developme }\end{array}$ & $\begin{array}{l}\text { ATION OF } \\
\text { esearch } \\
\text { Constraint }\end{array}$ & ECOVERY PO & $\begin{array}{r}\text { ENTIAL } \\
13.5 \\
6.0 \\
1.0\end{array}$ & $\begin{array}{l}6.8 \\
5.5 \\
2.5\end{array}$ & & & $\begin{array}{r}11.5 \\
3.5\end{array}$ \\
\hline $\begin{array}{l}\text { ENVIRON } \\
\text { Specific Pri } \\
\text { Generic Pr }\end{array}$ & $\begin{array}{l}\text { ENTAL ST } \\
\text { ams } \\
\text { ams }\end{array}$ & & & & $\begin{array}{l}5.0 \\
2.0 \\
\end{array}$ & $\begin{array}{l}2.5 \\
4.5 \\
\end{array}$ & $\begin{array}{l}7.5 \\
6.5 \\
\end{array}$ \\
\hline Totals & & & 213.5 & 20.1 & 7.0 & 7,0 & 247.6 \\
\hline
\end{tabular}

Total budget authorizations for FY1981 - FY1986 (FY1980 Dollars) 